\title{
Grade and Tonnage Model for Tungsten Skarn Deposits-2020 Update
}

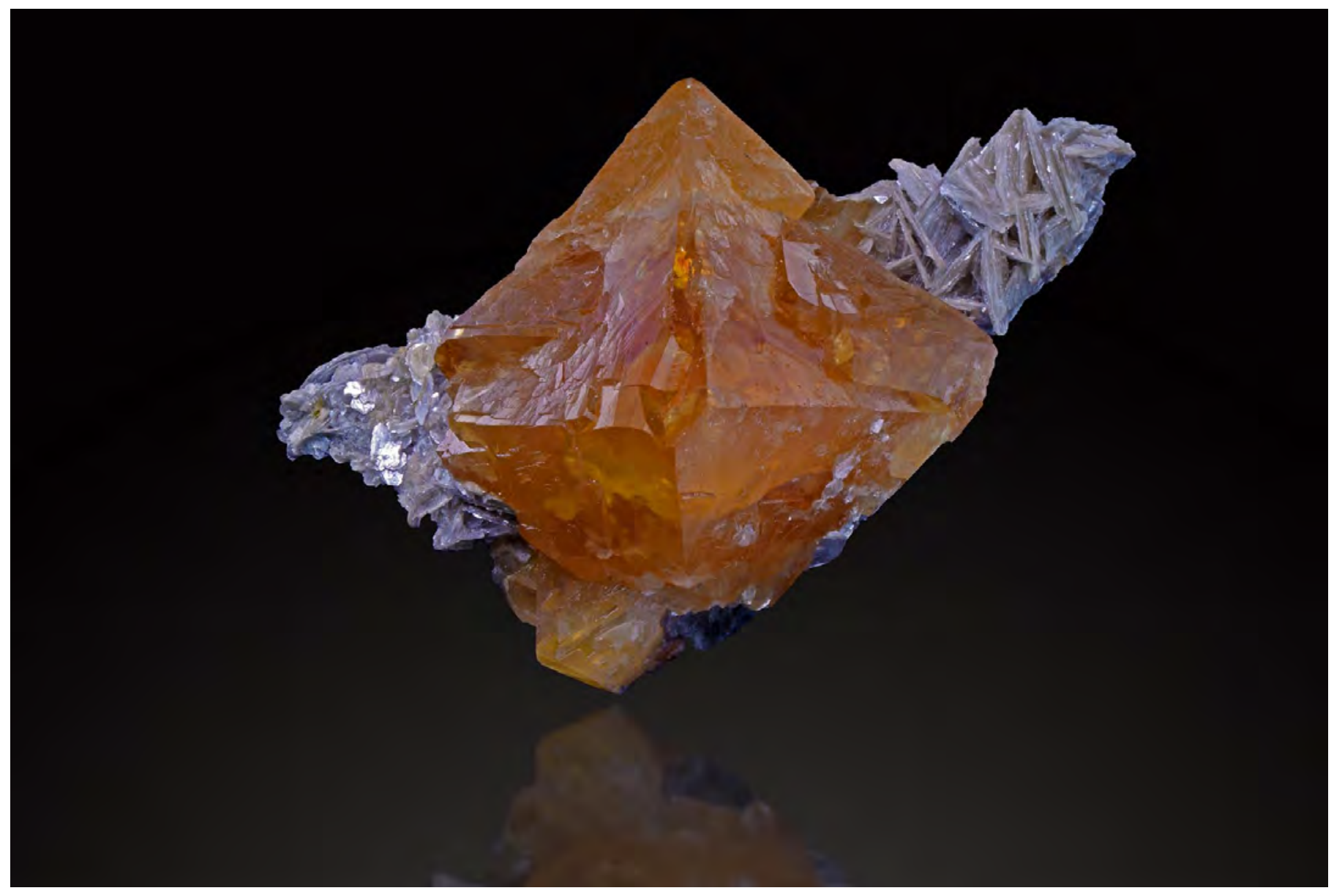

Scientific Investigations Report 2020-5085 
Cover. Sample of scheelite on muscovite, 6 centimeters, from Xuebaoding, Pingwu County, Sichuan Province, China. Scheelite is the dominant tungsten ore mineral in tungsten skarn deposits. Photograph by Carlin Green. 


\section{Grade and Tonnage Model for Tungsten Skarn Deposits-2020 Update}

By Carlin J. Green, Graham W. Lederer, Heather L. Parks, and Michael L. Zientek

Scientific Investigations Report 2020-5085 


\title{
U.S. Department of the Interior \\ DAVID BERNHARDT, Secretary
}

\author{
U.S. Geological Survey \\ James F. Reilly II, Director
}

U.S. Geological Survey, Reston, Virginia: 2020

For more information on the USGS - the Federal source for science about the Earth, its natural and living resources, natural hazards, and the environment—visit https://www.usgs.gov or call 1-888-ASK-USGS.

For an overview of USGS information products, including maps, imagery, and publications, visit https://store.usgs.gov/.

Any use of trade, firm, or product names is for descriptive purposes only and does not imply endorsement by the U.S. Government.

Although this information product, for the most part, is in the public domain, it also may contain copyrighted materials as noted in the text. Permission to reproduce copyrighted items must be secured from the copyright owner.

Suggested citation:

Green, C.J., Lederer, G.W., Parks, H.L., and Zientek, M.L., 2020, Grade and tonnage model for tungsten skarn deposits - 2020 update: U.S. Geological Survey Scientific Investigations Report 2020-5085, 23 p., https://doi.org/ 10.3133/sir20205085.

ISSN 2328-0328 (online) 


\section{Acknowledgments}

The authors acknowledge the contributions of the U.S. Geological Survey Mineral Resources Program's Mineral Resource Assessment Training participants, including Allen Andersen, Mitchell Bennett, Damon Bickerstaff, Phil Brown II, George Case, Josh Coyan, Kevin Denton, Connie Dicken, Maggie Goldman, Garth Graham, Erin Marsh, Celestine Mercer, Federico Solano, Ryan Taylor, and Kathryn Watts. The authors also acknowledge Jane Hammarstrom and Gilpin Robinson for their guidance and review as well as George Case and Allen Andersen for their thoughtful peer reviews of this manuscript. 



\section{Contents}

Acknowledgments ……...................................................................................................................

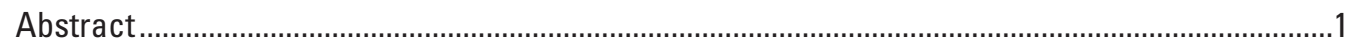

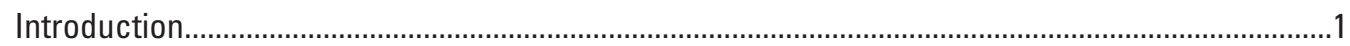

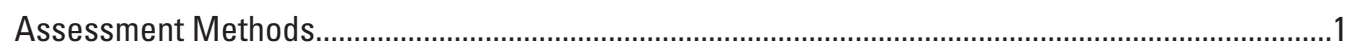

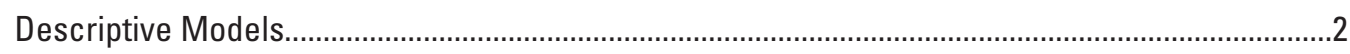

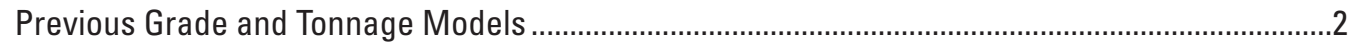

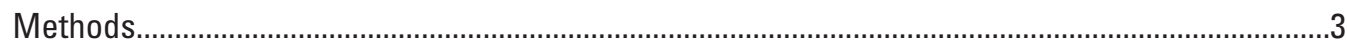

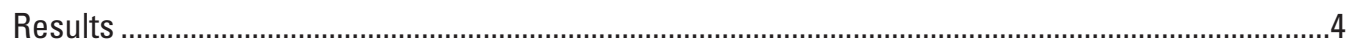

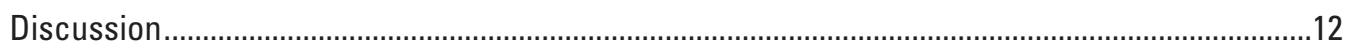

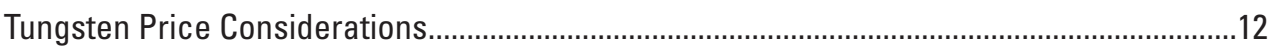

Effect of Grade and Tonnage Model Parameters on MapMark4 Simulations..........................12

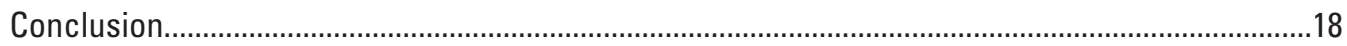

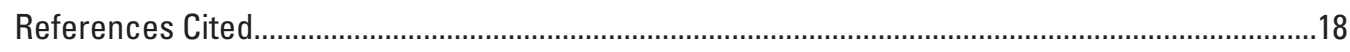

\section{Figures}

1. Graph showing cumulative frequency of ore tonnages of the 41 tungsten skarn deposits selected for inclusion in this model....................................................................

2. Graph showing the cumulative frequency of tungsten trioxide grade of the 41 tungsten skarn deposits selected for inclusion in this model...........................................5

3. Bivariate plot of log-transformed ore grade and tonnage showing the distribution of the 41 deposits included in this tungsten skarn model..

4. Graphs of log-transformed tonnage values and other statistical results for the 41 tungsten skarn deposits included in this model .....................................................10

5. Graphs of log-transformed grade values and other statistical results for the 41 tungsten skarn deposits included in this model..

6. Bivariate plot of log-transformed ore grade and tonnage showing the current model tonnage compared with that of the previous model for tungsten skarn deposits prepared by Menzie and others (1992)

7. Graph showing tungsten concentrate prices from 1900 to 2019 , with nominal unit values, inflation-adjusted unit values, 20 -year average price, and the recommended value per metric ton of $\mathrm{WO}_{3}$

8. Bivariate plot of log-transformed grade and tonnage for simulation results using different test parameters in MapMark4.

9. Histograms of contained tungsten trioxide for simulation results using different test parameters in MapMark4.

10. Bar charts comparing the mean contained and recoverable tungsten trioxide for simulation results using different test parameters in the MapMark4 and Resource Assessment Economic Filter software. 


\section{Tables}

1. Summary statistics for tungsten skarn grade and tonnage models ....................................

2. Tonnage, grade, and location data for 41 tungsten skarn deposits

3. Test run parameters and simulation results for the current tungsten skarn grade and tonnage model and one previous model using MapMark4 and RAEF software.

\section{Conversion Factors}

U.S. customary units to International System of Units

\begin{tabular}{lcll}
\hline \multicolumn{1}{c}{ Multiply } & By & To obtain \\
\hline & Length & \\
\hline mile (mi) & 1.609 & kilometer $(\mathrm{km})$ & \\
\hline & Mass & \\
\hline pound, avoirdupois $(\mathrm{lb})$ & 0.4536 & kilogram $(\mathrm{kg})$ & \\
ton, short $(2,000 \mathrm{lb})$ & 0.9072 & metric ton $(\mathrm{t})$ & \\
ton, long $(2,240 \mathrm{lb})$ & 1.016 & metric ton $(\mathrm{t})$ & \\
\hline
\end{tabular}

International System of Units to U.S. customary units

\begin{tabular}{lcll}
\hline & Multiply & By & To obtain \\
\hline & Length & \\
\hline kilometer $(\mathrm{km})$ & 0.6214 & mile $(\mathrm{mi})$ \\
\hline \multicolumn{3}{c}{ Mass } & \\
\hline kilogram $(\mathrm{kg})$ & 2.205 & pound avoirdupois $(\mathrm{lb})$ \\
metric ton $(\mathrm{t})$ & 1.102 & ton, short $[2,000 \mathrm{lb}]$ \\
metric ton $(\mathrm{t})$ & 0.9842 & ton, long $[2,240 \mathrm{lb}]$ \\
\hline
\end{tabular}

\section{Abbreviations}

$\begin{array}{ll}\text { JORC } & \text { Joint Ore Reserves Committee } \\ \text { KDE } & \text { kernel density estimate } \\ \text { MTU } & \text { metric ton unit } \\ \text { NI } & \text { National Instrument } \\ \text { PDF } & \text { probability distribution function } \\ \text { ppm } & \text { part per million } \\ \text { RAEF } & \text { Resource Assessment Economic Filter } \\ \text { USGS } & \text { U.S. Geological Survey } \\ \text { W } & \text { tungsten } \\ \text { WO }_{3} & \text { tungsten trioxide }\end{array}$




\title{
Grade and Tonnage Model for Tungsten Skarn Deposits-2020 Update
}

\author{
By Carlin J. Green, Graham W. Lederer, Heather L. Parks, and Michael L. Zientek
}

\section{Abstract}

This report presents an updated grade and tonnage model for tungsten skarn deposits. As a critical component of the U.S. Geological Survey's three-part form of quantitative mineral resource assessment, robust grade and tonnage models are essential to transforming mineral resource assessments into effective tools for decision makers. Using the best data available at the time of publication, this represents the first attempt in nearly 30 years to capture current mineral inventory and cumulative production data for worldwide tungsten skarn deposits. The accuracy of modern assessments of undiscovered tungsten skarn resources is highly influenced by the use of current data on the distribution of the grades and tonnages of well-explored tungsten skarn deposits. Primary factors affecting the changes to these distributions in the model presented here compared with those of previous models are the inclusion of important deposits, especially those in China that had been omitted in previous models; expanded mineral inventories resulting from increased exploration; and changes to international reporting standards. These factors have resulted in dramatic increases in average ore tonnage and slight decreases in the average grade of tungsten skarn deposits compared with previous models. Large increases in contained metal are observed among many of the individual deposits incorporated within this model that were also included in previous tungsten skarn grade and tonnage models. This report also provides recommendations for input parameters related to grade and tonnage models to use with software tools designed to facilitate the three-part form of quantitative mineral resource assessments.

\section{Introduction}

Understanding the distribution of Earth's mineral resource endowment requires, as a primary input, fundamental information on the quantity and quality of discovered mineral resources. Mineral resource and cumulative production data provide the basic information needed to construct reliable grade and tonnage models for specific types of mineral deposits. In turn, a well-defined grade and tonnage model represents an essential component of the U.S. Geological Survey's (USGS's) three-part form of quantitative mineral resource assessment (Singer, 1993; Singer and Menzie, 2010).

For more than a century, the security of the tungsten mineral supply chain has been a focus of coordinated U.S. Government policy. In 2018, tungsten was designated as a critical mineral primarily owing to the concentration of the global supply and the high proportion of U.S. demand met through imports of raw materials (Fortier and others, 2018; Shedd, 2020). The updated grade and tonnage model for tungsten skarns presented here has been prepared to facilitate regional assessments of undiscovered tungsten resources in response to section 4 of Executive Order No. 13817 (Executive Office of the President, 2017). Tungsten occurs in several deposit types, namely skarn, vein, breccia, porphyry, and disseminated or greisen types, among others. Of these deposit types, tungsten skarn represents the leading source of production historically and accounts for the largest share of discovered resources (Schubert and others, 2006; Pitfield and Brown, 2011; Werner and others, 2014). This grade and tonnage model applies to deposits matching the descriptive model for tungsten skarn (Cox, 1986; Hammarstrom and others, 1995). The model is a necessary component for determining the possible economic viability of tungsten resources in the United States and provides a foundation for land-use planning (Singer and Menzie, 2010).

\section{Assessment Methods}

In the three-part form of mineral-resource assessment, geographic areas (permissive tracts) are delineated using geologic, geochemical, mineral occurrence, and geophysical data to identify areas with features typical of the type of deposit under consideration. Permissive tracts represent the surface projection of part of the Earth's crust and overlying surficial materials to a predetermined depth where undiscovered mineral resources may be present; the criteria used to select the permissive volume of rock, or assessment unit, are provided by descriptive mineral deposit models and mineral systems models (Hammarstrom and others, 2019). 
The amount of metal in undiscovered deposits is estimated using grade and tonnage models derived from information about known deposits, which serve as analogs for the resources in undiscovered deposits. Probabilistic estimates of numbers of undiscovered deposits are made at different confidence levels using a variety of estimation strategies to express the degree of belief that some fixed but unknown number of deposits exists within the permissive tract. Estimates are consistent with the known deposits that define grade and tonnage models (Singer, 2007). These estimates are measures of the favorability of the tract and of the estimator's uncertainty about what may exist (Singer, 2007). Estimates are combined with the grade and tonnage model in a Monte Carlo simulation to estimate in situ amounts of metal. These estimates can be further refined by applying an economic filter to consider what part of the simulated resource might be economic.

\section{Descriptive Models}

Tungsten skarns are characterized by stratiform, tabular, and lens-like orebodies that extend from tens to hundreds of meters along lithologic contacts. Skarns are associated with the contact zone between carbonate-bearing rocks and relatively evolved felsic intrusive rocks, such as tonalite, granodiorite, quartz monzonite, and I- or S-type granites (Hammarstrom and others, 1995). Plutons associated with tungsten skarns tend to be more differentiated and have stronger crustal signatures from contamination with sedimentary material than other metallic skarns, such as copper or zinc (Ray, 1995; Meinert and others, 2005). Host carbonate lithologies include pure to impure limestones, dolostone, marble, and calcareous to carbonaceous pelites (Dawson, 1984). The primary ore minerals are scheelite, molybdenite, sphalerite, and powellite; common gangue minerals include diopside-hedenbergite pyroxene and grossular-andradite garnet (Cox, 1986).
Previous descriptive models for tungsten skarn are presented in Cox $(1983,1986)$, Dawson (1984), Hammarstrom and others (1995), and Ray (1995). The descriptive models highlight general features of tungsten skarn deposits (Einaudi and others, 1981; Einaudi and Burt, 1982) and refer to specific examples, such as Pine Creek (Newberry, 1982), Mactung (Dick and Hodgson, 1982), and Strawberry (Nokleberg, 1981). In addition, several compilations of mineral resource inventory data include information on tungsten skarn deposits (Meinert and others, 2005; Sinclair and others, 2014; Werner and others, 2014).

\section{Previous Grade and Tonnage Models}

Several grade and tonnage models for tungsten skarn deposits have been published previously (Menzie and Jones, 1983; Menzie and Jones, 1986; Menzie and others, 1992; John and Bliss, 1993). The 28 deposits and grade and tonnage distributions in the initial grade and tonnage model (Menzie and Jones, 1983) are mirrored (that is, the same 28 deposits and identical grade and tonnage distributions are used) in the superseding publication (Menzie and Jones, 1986), which was published as part of a comprehensive compilation of mineral deposit models (Cox and Singer, 1986). The tungsten skarn model was later updated with eight additional deposits (Menzie and others, 1992) and incorporated into the EMINERS (Economic Mineral Resource Simulator) software application (Duval, 2002, 2012). A tungsten skarn model for Nevada (John and Bliss, 1993) that is based on tungsten production data (Stager and Tingley, 1988) lacks estimates of in-place resources for most sites and, therefore, does not represent well-delineated deposits. The summary statistics for these previous models are given in table 1.

In addition to the grade and tonnage models for tungsten skarn, models for tungsten quartz-wolframite vein deposits (Menzie and others, 1992), as well as

Table 1. Summary statistics for tungsten skarn grade and tonnage models.

$\left[\mathrm{WO}_{3}\right.$, tungsten trioxide $]$

\begin{tabular}{|c|c|c|c|c|c|c|c|}
\hline \multirow[b]{2}{*}{ Reference } & \multirow[b]{2}{*}{$\begin{array}{c}\text { Number } \\
\text { of } \\
\text { deposits }\end{array}$} & \multicolumn{3}{|c|}{ Tonnage, in metric tons } & \multicolumn{3}{|c|}{ Grade, in percent $\mathrm{WO}_{3}$} \\
\hline & & $\begin{array}{l}\text { 90th } \\
\text { percentile of } \\
\text { deposits }\end{array}$ & $\begin{array}{c}\text { 50th } \\
\text { percentile of } \\
\text { deposits }\end{array}$ & $\begin{array}{c}\text { 10th } \\
\text { percentile of } \\
\text { deposits }\end{array}$ & $\begin{array}{c}\text { 90th } \\
\text { percentile } \\
\text { of deposits }\end{array}$ & $\begin{array}{c}\text { 50th } \\
\text { percentile } \\
\text { of deposits }\end{array}$ & $\begin{array}{c}\text { 10th } \\
\text { percentile } \\
\text { of deposits }\end{array}$ \\
\hline Menzie and Jones (1983) & 28 & 50,000 & $1,100,000$ & $22,000,000$ & 0.34 & 0.67 & 1.4 \\
\hline Menzie and Jones (1986) & 28 & 50,000 & $1,100,000$ & $22,000,000$ & 0.34 & 0.67 & 1.4 \\
\hline Menzie and others (1992) & 36 & 41,000 & 800,000 & $18,000,000$ & 0.30 & 0.64 & 1.3 \\
\hline This study & 41 & $1,290,000$ & $6,030,000$ & $49,320,000$ & 0.24 & 0.44 & 0.88 \\
\hline
\end{tabular}


porphyry-tungsten molybdenum deposits and molybdenumtungsten greisen deposits, have been published previously (Kotlyar and others, 1995).

\section{Methods}

The goal of characterizing the grade and tonnage distributions of tungsten skarn deposits is to focus on a single deposit type with well-defined, mappable geologic criteria. An initial list of known tungsten deposits was compiled from mineral databases (Meinert and others, 2005; Sinclair and others, 2014; Werner and others, 2014). Importantly, these compilations retain the deposit type classification, allowing tungsten skarn sites to be selected individually. For example, the World Tin and Tungsten Deposit Database (Sinclair and others, 2014) contains more than 954 individual sites and 76 group sites, of which 136 have tungsten listed as a commodity and skarn listed as the deposit type.

After querying various databases, sorting through several hundred deposits with variant names, and obtaining grade and tonnage data for those deposits, only those deposits that were confirmed to be well-explored tungsten skarn sites were selected for inclusion in the model. Other deposit types, including other skarn deposit types, such as iron skarn and copper skarn deposits, were removed. Similarly, combination deposits that consist of part skarn and part greisen or disseminated deposits were also removed. This process resulted in the removal of certain well-known tungsten deposits, such as the Yaogangxian Mine in Hunan, China, which contains a significant component of vein- or greisen-type mineralization in addition to tungsten skarn mineralization. Although some deposits of this hybrid nature are significant sources of tungsten, their exclusion in a tungsten skarn grade and tonnage model is necessary to ensure that the probable size and grade of undiscovered tungsten skarn deposits is reflective of the characteristic distributions of size and grade among known tungsten skarn deposits (Singer and Menzie, 2010; Hammarstrom and others, 2019). To maintain consistency, deposits included in this grade and tonnage model are formed by the same type of mineralizing event as other deposits used in the model and are of the same deposit type as other deposits used in the model (Barton and others, 1995; Hammarstrom and others, 2019). Additionally, certain other deposits that were present in previous iterations of tungsten skarn grade and tonnage models were removed where additional exploratory work indicated that the mineral inventory was not fully defined (for example, Strawberry Mine in California and Salau Mine in France). Deposits that are not completely delineated - that is, where any part of the boundary is open - are considered to be "undiscovered" for the purposes of the USGS three-part form of assessment (Singer and Menzie, 2010). Duplicate entries were combined, and conflicting values for grades and tonnages were resolved by calculating the total tonnage and average grade of the original resource. For deposits with multiple values, the largest tonnage reported at the lowest cutoff grade was used in the model. In general, resources are reported inclusive of reserves, meaning that reserves are included in the resource total. If resources were reported exclusive of reserves, the reserves' tonnage was added to the resource tonnage to obtain total tonnage and the weighted average grade was calculated using equation 1 :

$$
G_{\text {average }}=\frac{\left(G_{\text {resources }} \times T_{\text {resources }}\right)+\left(G_{\text {reserves }} \times T_{\text {reserves }}\right)}{\left(T_{\text {resources }}+T_{\text {reserves }}\right)},
$$

where $\mathrm{G}$ is the tungsten grade expressed as weight percent tungsten trioxide $\left(\mathrm{WO}_{3}\right)$ and $\mathrm{T}$ is ore tonnage in metric tons. Similarly, for deposits with historical production, the amount of reported mine production was aggregated and added to the resource tonnage using equation 2 :

$$
G_{\text {average }}=\frac{\left(G_{\text {resaurces }} \times T_{\text {resources }}\right)+\left(G_{\text {production }} \times T_{\text {production }}\right)}{\left(T_{\text {resources }}+T_{\text {production }}\right)} .
$$

The average grade and total tonnage result refers to the total resource endowment for the deposit and represents the pre-mining in-place resource estimate for the deposit. Often, cumulative production is given in units other than ore tonnage, such as tons of tungsten metal (W), or metric ton units (MTUs) of $\mathrm{WO}_{3}$. To convert metal content to $\mathrm{WO}_{3}$, the stoichiometric conversion factor of 0.793 was used. An MTU is an industry standard that refers to 10 kilograms, or one hundredth of a metric ton. Alternatively, some references use a short ton unit to represent one hundredth of a short ton, or 20 pounds. For deposits where total mineral inventory was calculated from production, reserves, and (or) various categories of indicated and inferred resources, tonnage and grade data are reported using the number of significant figures associated with the least precise input to avoid misrepresenting the level of precision associated with reported values.

To ensure that the population of discovered deposits in the grade and tonnage model accurately represents the population of undiscovered deposits, a spatial aggregation rule was applied (Singer and Menzie, 2010). Previous grade and tonnage models used spatial aggregation rules ranging from 1 kilometer (km; John and Bliss, 1993) to $10 \mathrm{~km}$ (Menzie and Jones, 1986) and aggregated all bodies of mineralized skarn associated with the contact of a particular intrusion (Menzie and others, 1992). Although most deposits in this model represent a single orebody or mineralized zone, spatially distinct deposits occurring along related lithologic contacts were aggregated using a spatial rule of $5 \mathrm{~km}$ from the center of the mineralized zone. For example, the Brejui deposit in Brazil includes the Barra Verde and the Boca de Laje Mines; the Dholpani and Bhurkhola deposits in Bhutan are two orebodies along the same contact; and the Pilot Mountain deposit in Nevada includes aggregate production and resource data for the Gunmetal, Garnet, and Desert Scheelite Mines. The 5-km distance also encompasses the footprint of very large deposits included in the model, such as Sangdong in South Korea and Tyrnyauz in Russia. 


\section{Results}

In total, 41 tungsten skarn deposits are included in this grade and tonnage model. The amount of mineralized rock in the deposits ranges from 405,000 to $76,450,000$ metric tons (fig. 1) with a grade ranging from 0.14 to 1.20 weight percent $\mathrm{WO}_{3}$ (fig. 2). The 90th, 50th, and 10th percentile intercepts are shown in figures 1 and 2 and summarized in table 1 . The grade and tonnage distribution of deposits in this model is plotted in figure 3. The list of deposits, their mineral endowments, and their locations are given in table 2. Statistical tests of the distributions of log-transformed tonnage and grade values show correspondence to a lognormal distribution with a standard deviation of 0.58 for tonnage (fig. 4) and 0.21 for grade (fig. 5).

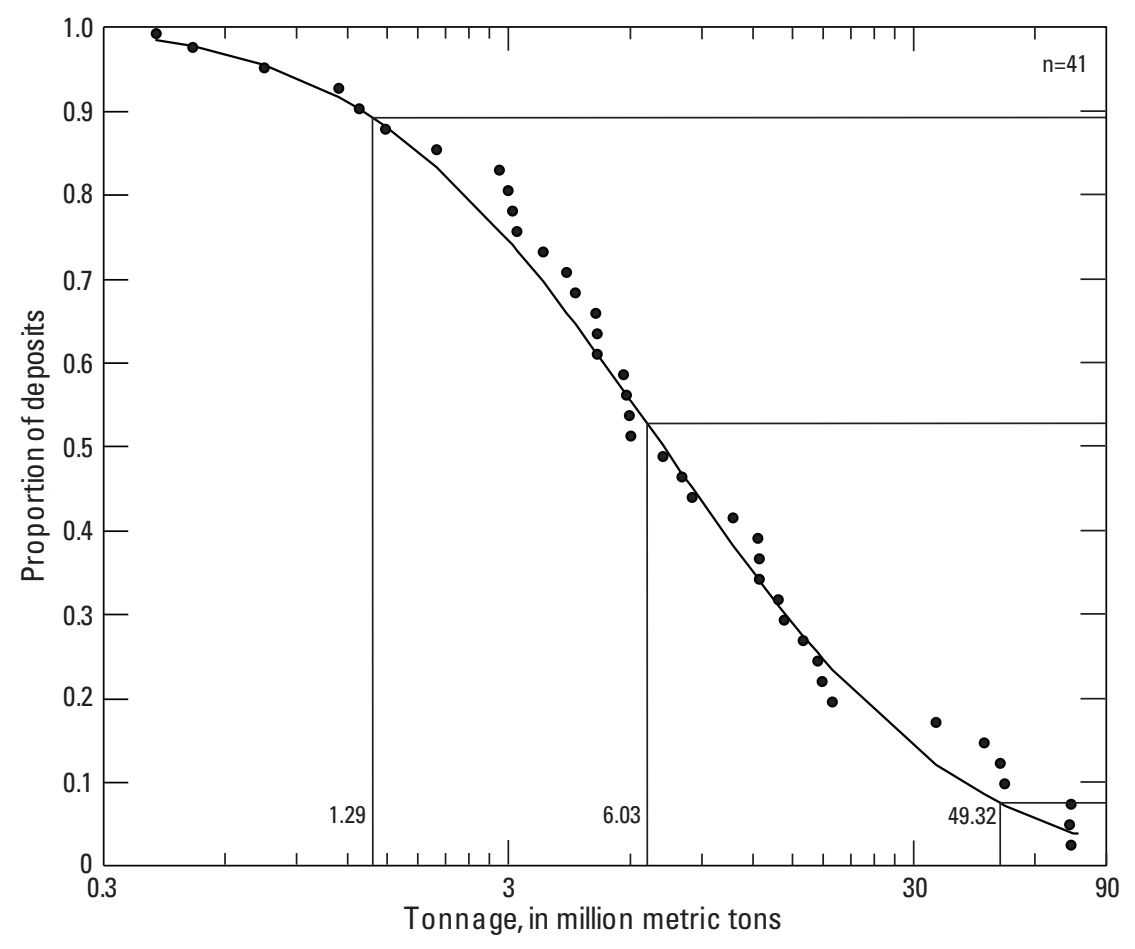

Figure 1. Cumulative frequency of ore tonnages of the 41 tungsten skarn deposits selected for inclusion in this model. Each point represents an individual deposit; the lognormal distribution is plotted as a continuous curve. The 90th, 50th, and 10th percentile intercepts are plotted. Data are from table 2 of this report. 


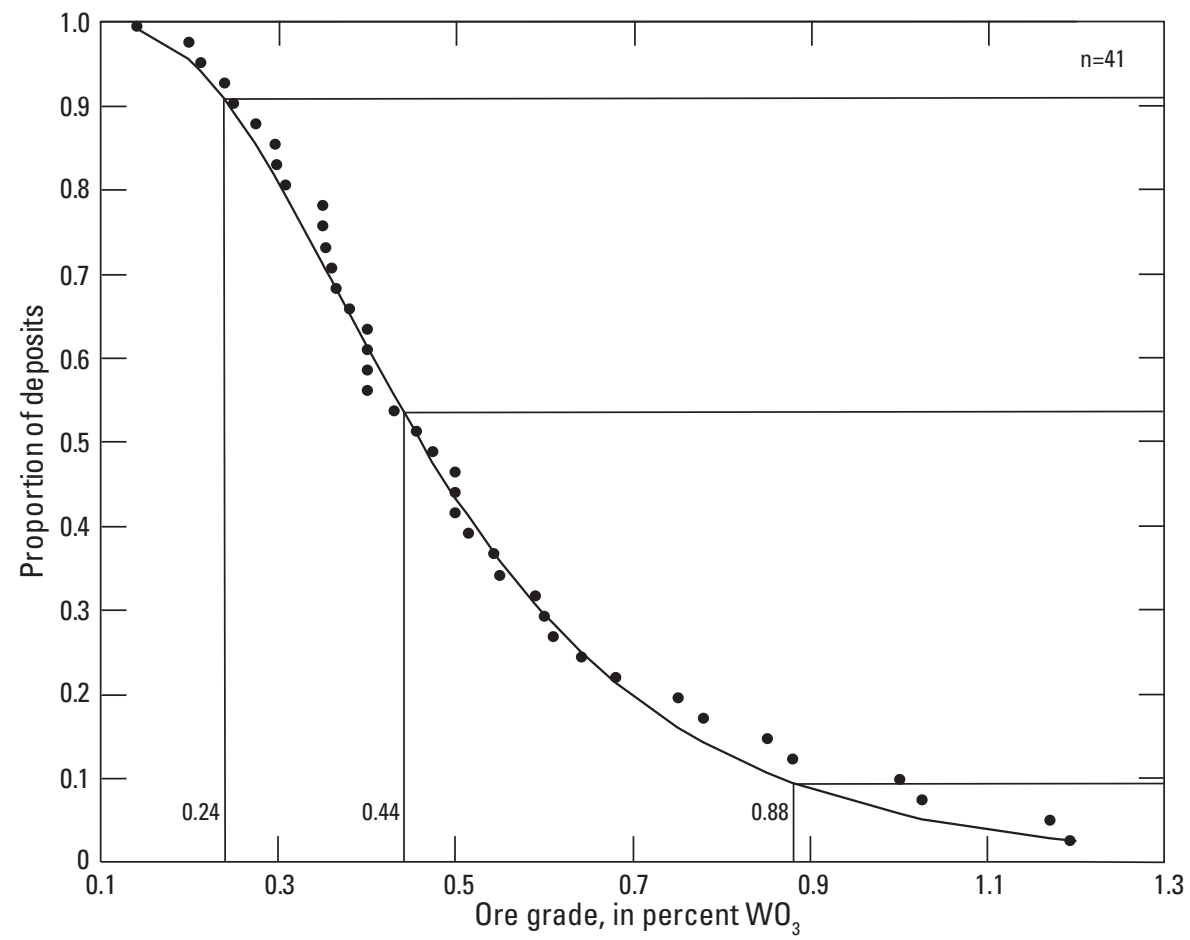

Figure 2. Cumulative frequency of tungsten trioxide $\left(\mathrm{WO}_{3}\right)$ grade of the 41 tungsten skarn deposits selected for inclusion in this model. Each data point represents an individual deposit; the lognormal distribution is plotted as a continuous curve. The 90th, 50th, and 10th percentile intercepts are plotted. Data are from table 2 of this report. 


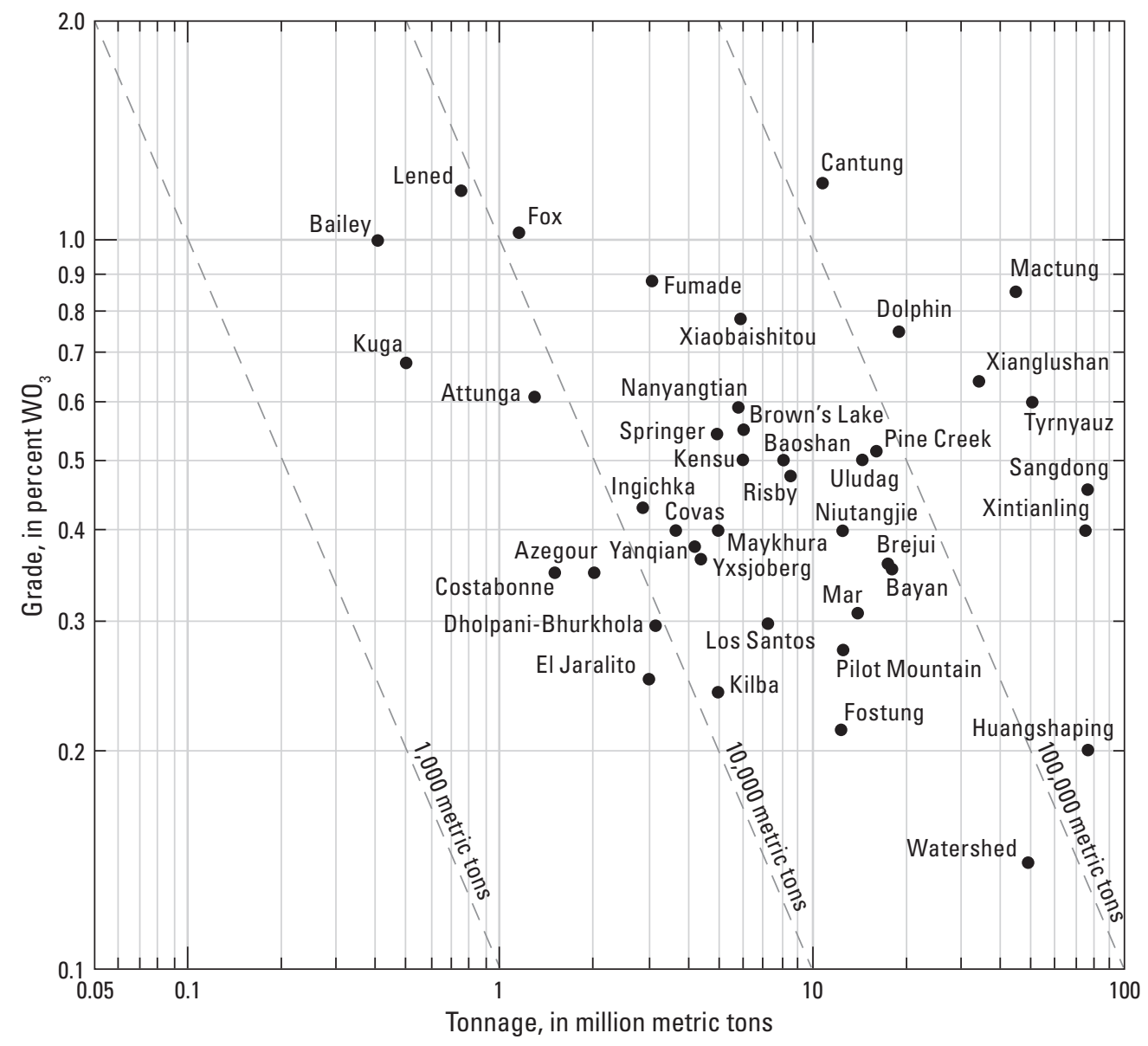

Figure 3. Bivariate plot of log-transformed ore grade and tonnage showing the distribution of the 41 deposits included in this tungsten skarn model. Dashed diagonal lines show the amount of contained tungsten metal, in metric tons. Data are from table 2 of this report. $\mathrm{WO}_{3}$, tungsten trioxide 
Table 2. Tonnage, grade, and location data for 41 tungsten skarn deposits.

[Tonnage and grade data are reported using the number of significant figures associated with the least precise input]

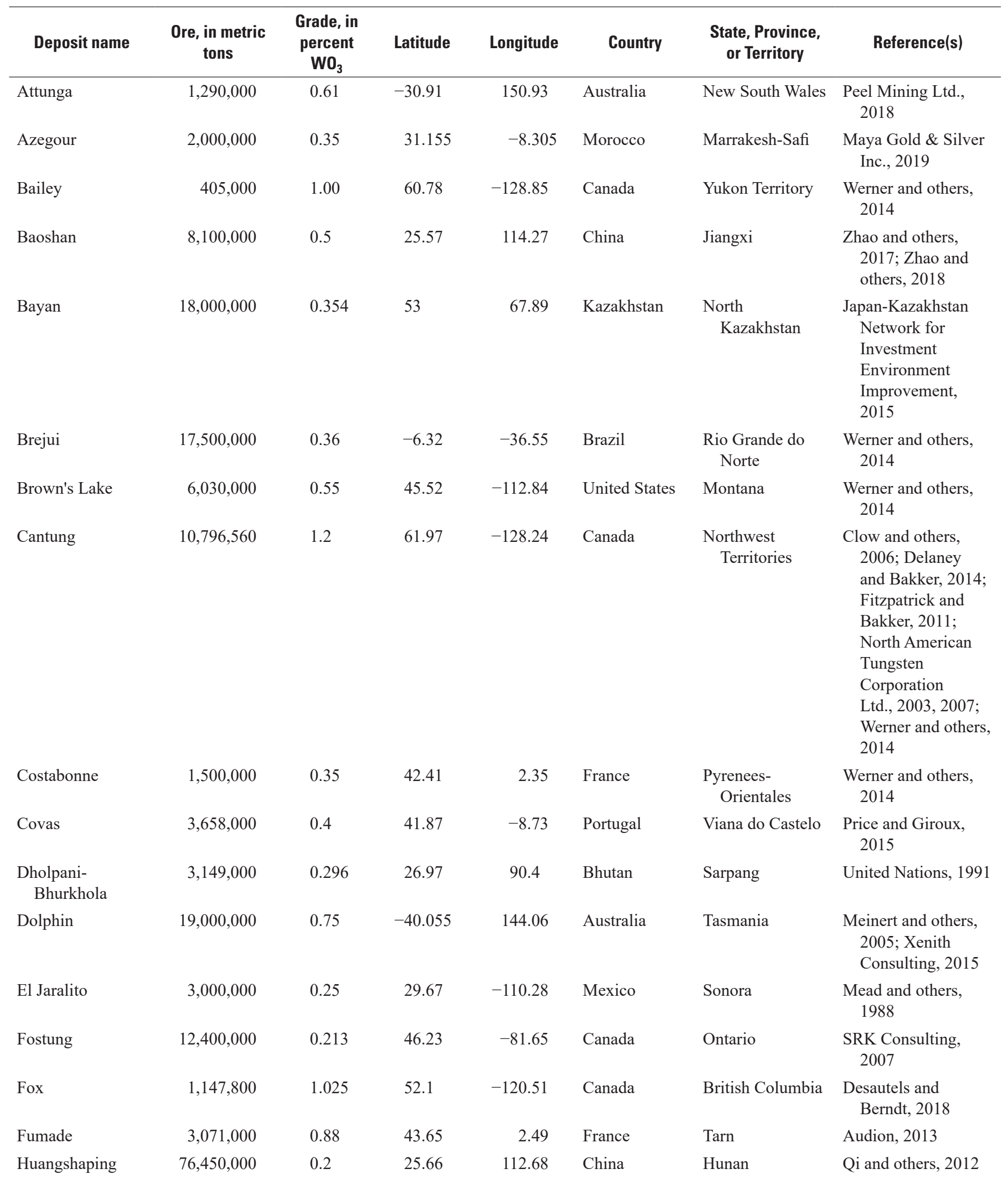


Table 2. Tonnage, grade, and location data for 41 tungsten skarn deposits.-Continued

[Tonnage and grade data are reported using the number of significant figures associated with the least precise input]

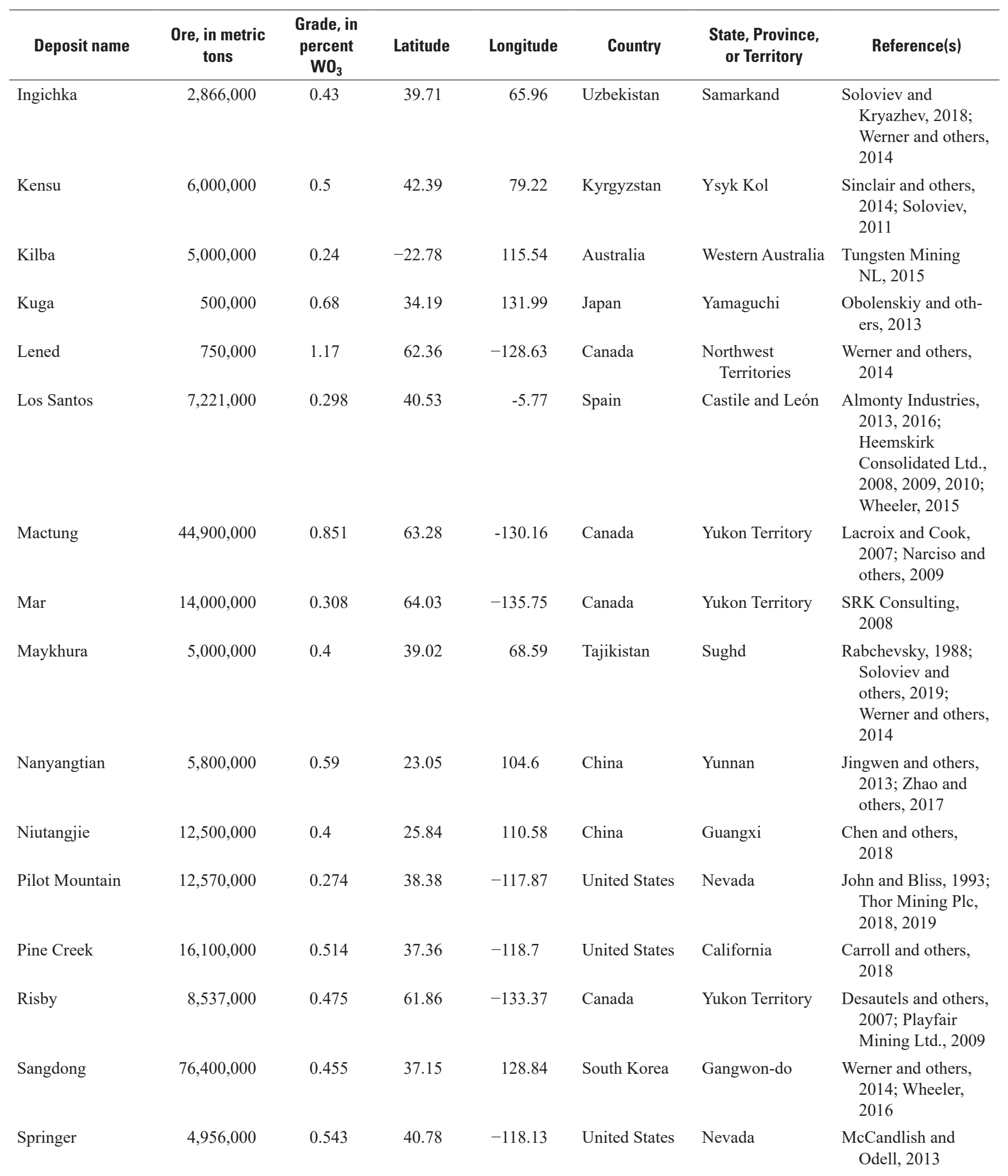


Table 2. Tonnage, grade, and location data for 41 tungsten skarn deposits. - Continued

[Tonnage and grade data are reported using the number of significant figures associated with the least precise input]

\begin{tabular}{|c|c|c|c|c|c|c|c|}
\hline Deposit name & $\begin{array}{l}\text { Ore, in metric } \\
\text { tons }\end{array}$ & $\begin{array}{c}\text { Grade, in } \\
\text { percent } \\
\mathrm{WO}_{3}\end{array}$ & Latitude & Longitude & Country & $\begin{array}{l}\text { State, Province, } \\
\text { or Territory }\end{array}$ & Reference(s) \\
\hline Tyrnyauz & $50,800,000$ & 0.6 & 43.39 & 42.86 & Russia & $\begin{array}{r}\text { Kabardino- } \\
\text { Balkaria }\end{array}$ & $\begin{array}{l}\text { Rabchevsky, 1988; } \\
\text { Werner and others, } \\
2014\end{array}$ \\
\hline Uludag & $14,500,000$ & 0.5 & 40.09 & 29.18 & Turkey & Bursa & $\begin{array}{l}\text { Werner and others, } \\
2014\end{array}$ \\
\hline Xianglushan & $34,300,000$ & 0.641 & 29.29 & 114.37 & China & Jiangxi & $\begin{array}{l}\text { Dai and others, 2018; } \\
\text { Zhao and others, } \\
2017\end{array}$ \\
\hline Xiaobaishitou & $5,900,000$ & 0.78 & 41.89 & 95.3 & China & Xinjiang & $\begin{array}{l}\text { Deng and others, } \\
2017\end{array}$ \\
\hline Yanqian & $4,400,000$ & 0.365 & 26.29 & 115.67 & China & Jiangxi & $\begin{array}{l}\text { Zhao and others, } \\
2018\end{array}$ \\
\hline Yxsjoberg & $4,200,000$ & 0.38 & 60.04 & 14.77 & Sweden & Orebro & $\begin{array}{l}\text { Sinclair and others, } \\
\text { 2014; Werner and } \\
\text { others, } 2014\end{array}$ \\
\hline
\end{tabular}




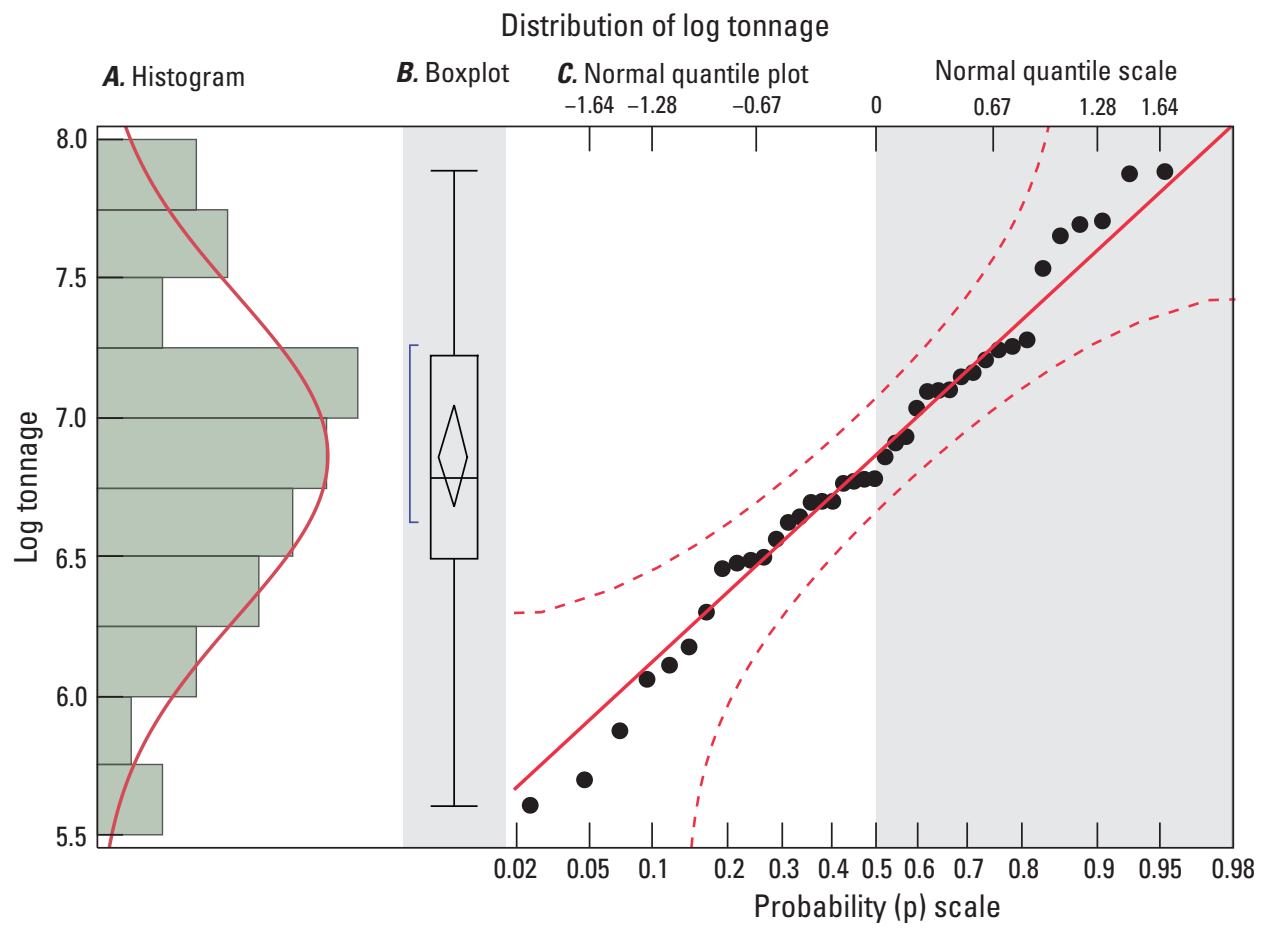

EXPLANATION

_ Normal (6.86111, 0.57754)
D. Summary statistics
Mean
Standard deviation

Figure 4. Graphs of log-transformed tonnage values and other statistical results for the 41 tungsten skarn deposits included in this model. These results demonstrate that the tonnage values do not differ significantly from a lognormal distribution and that standard deviation values are less than 1.0. $A$, histogram; $B$, box and whisker plot; $C$, normal quantile plot; $D$, summary of pertinent statistics, and $E$, results of the Shapiro-Wilk goodness-of-fit test for normality. The plotted data are from table 2 of this report. Ho, null hypothesis; $n$, total number of deposits; $\mathrm{p}$-value, probability value; $\mathrm{W}$, test statistic 


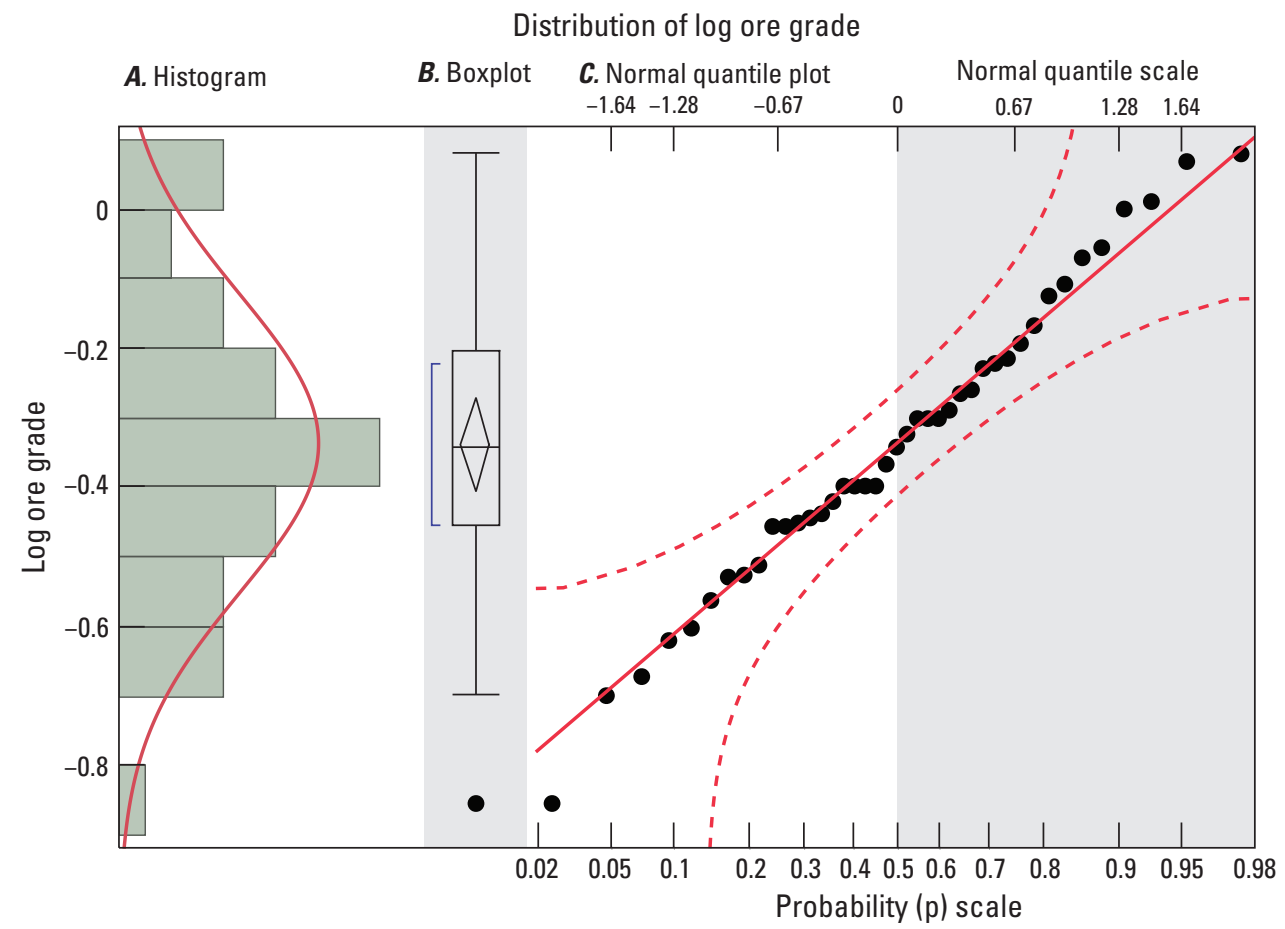

EXPLANATION
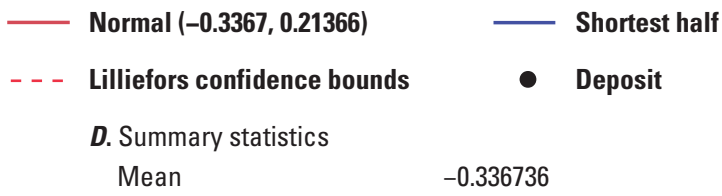

$\begin{array}{lr}\text { Mean } & -0.336736 \\ \text { Standard deviation } & 0.2136597 \\ \text { Standard error of the mean } & 0.033368 \\ \text { Upper 95\% mean } & -0.269297 \\ \text { Lower 95\% mean } & -0.404175 \\ n & 41\end{array}$

E. Shapiro-Wilk W test

$\begin{array}{rr}\text { W } & \text { Prob }<\text { W } \\ 0.988610 & 0.9497\end{array}$

Note: $\mathrm{Ho}=$ The data are from the normal distribution. Small p-values reject Ho.

Figure 5. Graphs of log-transformed grade values and other statistical results for the 41 tungsten skarn deposits included in this model. These results demonstrate that the grade values do not differ significantly from a lognormal distribution. $A$, histogram; $B$, box and whisker plot; $C$, normal quantile plot; $D$, summary of pertinent statistics, and $E$, results of the Shapiro-Wilk goodness-of-fit test for normality. The plotted data are from table 2 of this report. Ho, null hypothesis; $n$, total number of deposits; $\mathrm{p}$-value, probability value; $\mathrm{W}$, test statistic 


\section{Discussion}

Significant differences between the older global grade and tonnage models and the current updated model are notable, primarily the dramatic increase in the average ore tonnage. The great majority ( 90 percent) of deposits in the model presented here contains at least 1.29 million metric tons of ore (fig. 1), whereas the corresponding value in the model of Menzie and others (1992) was only 41,000 metric tons. Tonnage values for the 10th percentile also increased by more than 30 million metric tons, a change that has a significant effect on the estimation of undiscovered resources. Changes in grade are less dramatic between older models and the updated model presented here, varying only by a few tenths of one percent. Slight decreases in the average grades are more than offset by pronounced increases in tonnage, thus resulting in a greatly expanded total for contained metal within a given deposit. For example, several deposits are present in both models, and the difference between models can be observed in grade and tonnage plots, with the differences indicated by arrows drawn from the original value to the updated value for the same deposit (fig. 6). Large shifts in contained resources among deposits included in both models can be explained as an effect of additional exploration. Three important factors that heavily influence the changes observed between the previous iterations of the tungsten skarn grade and tonnage model and this updated model are (1) the availability of new data for important Chinese deposits, (2) the availability of expanded mineral resource inventories among known deposits, and (3) updated reporting standards; for example, the Joint Ore Reserves Committee [JORC] code and National Instrument [NI] 43-101 standards.

The stability of a particular grade and tonnage model is dependent on four primary statistical assumptions: (1) that tonnages and grades are not significantly different from a lognormal distribution, (2) that at least 20 deposits are used, (3) that standard deviations for log-transformed tonnage are less than 1.0, and (4) that there are no significant correlations between tonnage and grade (Singer and Menzie, 2010). The first three assumptions are unambiguously satisfied in this model; however, the correlation coefficient between tonnage and grade is -0.33 with a p-value of 0.03 , which indicates that the correlation is statistically significant. The dataset was scrutinized to identify potential sources of correlation, such as the inclusion of multiple deposit types, incomplete estimates of mineral endowment, effects of inclusion of deposits from nonmarket economies, or data processing errors. Absent these errors in reporting, a likely explanation is that correlation of grade and tonnage is a real phenomenon primarily related to economic effects. For example, various types of mine models show that operating costs decrease with increasing mine capacity; therefore, production costs tend to decrease with increasing tonnage (Camm, 1991, 1994). An increase in tonnage and mine lifetime may permit the cutoff grade to be lowered, resulting in an increase of contained and recoverable resources. Thus, the negative correlation in this model may be understood to be the result of economic factors that lead to lower cutoff grades concomitant with increases in tonnage. Consistent with the methods for compiling grade and tonnage information, the largest tonnages reported at the lowest cutoff grades form the basis for this model.

\section{Tungsten Price Considerations}

Tungsten prices have been well correlated with trends in supply and demand during the past century. For example, increased demand for tungsten during World War I, World War II, and the Korean War coincided with periods of high tungsten prices and U.S. Government price support (Stager and Tingley, 1988). Increased consumption of tungsten carbide led to price increases in the 1970s, followed by a decline in prices as production increased in China. More recently, tungsten prices have been characterized by high volatility (fig. 7). In general, the inflation-adjusted long-term average tungsten price has varied between $\$ 15,000$ and $\$ 35,000$ per metric ton of $\mathrm{WO}_{3}$ (U.S. Geological Survey, 2017; Shedd, 2020; U.S. Bureau of Labor Statistics, 2020). For example, in the 20-year period from 2000 to 2019, the average price of tungsten concentrates was approximately $\$ 26,500$ per metric ton of $\mathrm{WO}_{3}$.

As a result of price volatility, the economic criteria used to assess mineral resources must be reevaluated occasionally. One implication of changing tungsten prices is the effect on the cutoff grade used to conduct economic feasibility analyses of mineral resources. This relationship, with higher prices corresponding to lower reported cutoff grades, higher tonnages, and lower average grades, may explain some of the observed differences between this updated grade and tonnage model compared with previous models. The economic viability of a deposit is highly dependent on tungsten price considerations and the resulting shifts in cutoff grade. To assess whether some portion of a quantitative undiscovered mineral resource might be economic to extract, the Resource Assessment Economic Filter (RAEF) can be used (Shapiro and Robinson, 2019). For the purpose of calibrating the RAEF, a tungsten price of $\$ 26,500$ per metric ton of $\mathrm{WO}_{3}$ is recommended.

\section{Effect of Grade and Tonnage Model Parameters on MapMark4 Simulations}

The selection of an appropriate grade and tonnage model is the first of two primary inputs required for quantitative mineral resource assessment calculations by MapMark4, which is a software program that implements probability calculations in three-part mineral resource assessments (Ellefsen, 2017). The second input is the estimate of undiscovered deposits made by a panel of experts using available geological, geochemical, geophysical, and mineral site data within delineated permissive tracts. In addition to these numerical inputs, the software includes several parameters 
that must be specified by the user. This section discusses the influence of certain parameters related to the grade and tonnage modeling, how these parameters propagate through the calculation, and their ultimate effect on the quantitative assessment results.

Three parameters related to the grade and tonnage model affect how MapMark4 performs statistical calculations and models the input data with a continuous probability distribution function (PDF). The first parameter to be selected by the user is whether to truncate the distribution at the minimum and maximum observed values for grade and tonnage in the grade and tonnage model. The second parameter is the selection of the distribution type; the PDF can be constructed using the normal type or the kernel density estimate (KDE) type, with KDE being the preferred method for grade and tonnage models with greater than 50 deposits. The third parameter is the grade and tonnage model dataset, which must be tested for correlation between tonnage and grade.

To determine the influence of each parameter and test the robustness of the results, MapMark4 was run in different modes using the tungsten skarn grade and tonnage model presented here along with an example deposit estimate file, "ExampleDepEst4," which is included in the MapMark4 software package (Ellefsen, 2017). An additional test using the same deposit estimates was conducted with the previously published model (Menzie and others, 1992) for comparison. The test results, which are shown in table 3, illustrate the effect of grade and tonnage model parameter selection.

To test for the influence of the PDF type, the same grade and tonnage model and deposit estimates were run in two different modes. In the first test, the KDE PDF type was used, whereas in the second test, the normal PDF type was used. Both modes were run with truncation. To test for the effect of truncation, a third test was run without truncation using the KDE PDF type.

MapMark4 does not test for correlation between grade and tonnage; therefore, the user must verify that the grade and tonnage model input does not have a strong correlation. For example, large tonnage deposits may tend to have lower grades, resulting in a negative correlation. As a result, a simulation of deposits based on a correlated model may populate the large-tonnage-high-grade quadrant of the gradetonnage plot, even though no data from the grade and tonnage model are observed at those extreme values of contained metal. Although the probability of those deposits in the simulation are low, they can have a large effect on the amount of contained and recoverable resource totals. Furthermore, the effect of large-tonnage-high-grade deposits propagates through an economic filter.

Using the RAEF software package (Shapiro and Robinson, 2019) enables a test for the influence of correlation using empirical mode. In contrast to the MapMark4 Monte Carlo simulation, in which the PDFs for grade and tonnage are each sampled independently, empirical mode replaces each simulated deposit with a direct sample of the grade and tonnage model, preserving the pairings between grade and tonnage. If correlation is not a significant contributor of bias toward the large-tonnage-high-grade quadrant, then the RAEF empirical mode results and normal results should be comparable (figs. 8, 9).

Lastly, to illustrate the importance of grade and tonnage model selection and the effect of using the updated model, the simulation was run using a previously published tungsten skarn model (Menzie and others, 1992) as a truncated KDE PDF type. All tests were run with the same RAEF parameters, including a depth interval of 0 to $1 \mathrm{~km}$, one-product floatation, a tailings pond with a liner, a $\mathrm{WO}_{3}$ price of $\$ 26,500$, and a metallurgical recovery factor of $75 \%$.

The contained and recoverable $\mathrm{WO}_{3}$ resource tonnages are very similar for the empirical mode, normal PDF truncated, and KDE truncated test runs (table 3; fig. 10). The similarity in the results of empirical mode suggests that the slight negative correlation inherent to the grade and tonnage model does not have a major effect on the simulation results, so long as they are truncated. The untruncated model has much larger contained and recoverable $\mathrm{WO}_{3}$, as a result of high simulated grades of up to $10 \% \mathrm{WO}_{3}$ (fig. 10). These tests illustrate the robustness and limitations of the grade and tonnage model. Users are advised to select truncated distributions using MapMark4 and similar parameters in RAEF. 


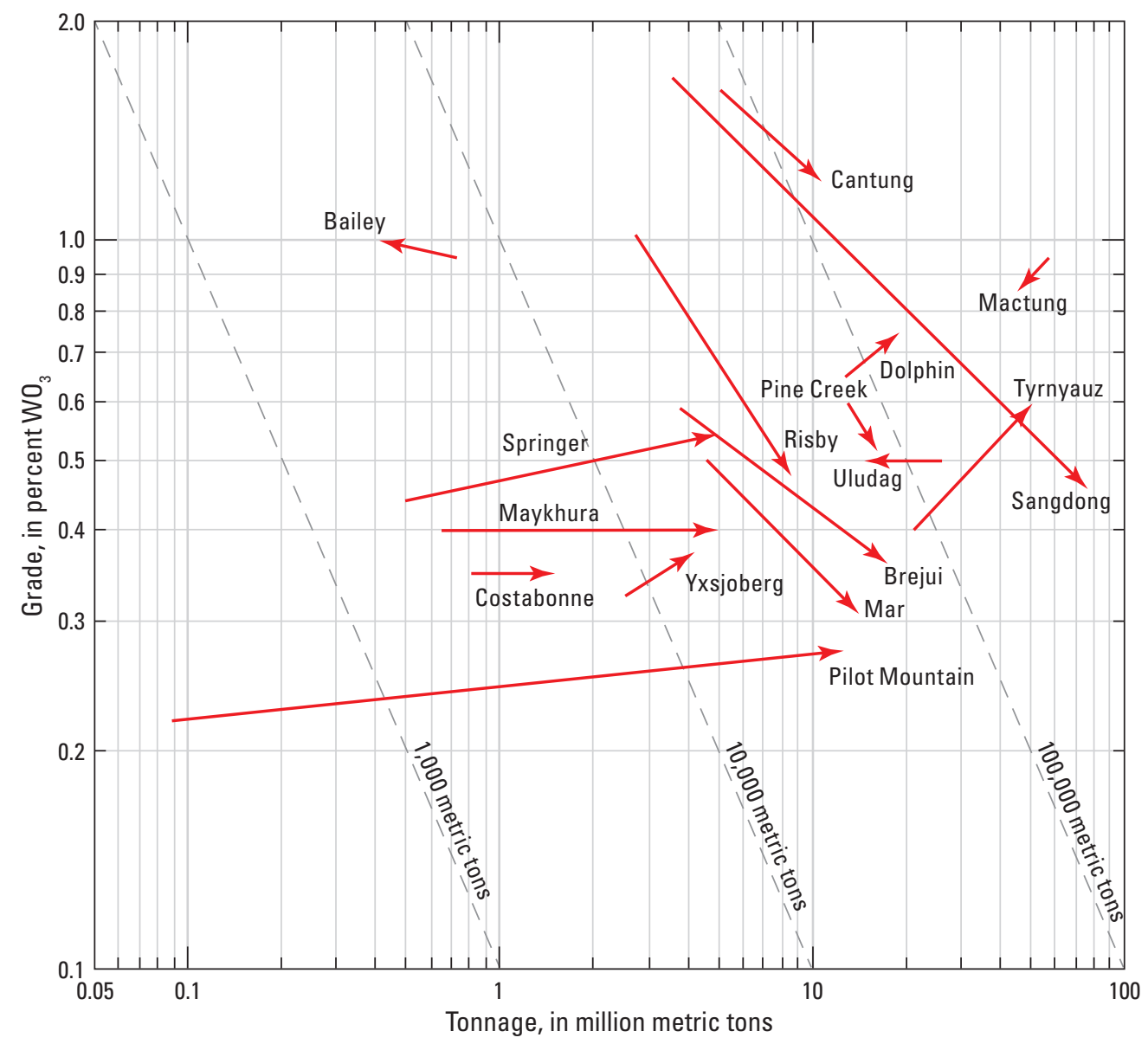

Figure 6. Bivariate plot of log-transformed ore grade and tonnage showing the current model tonnage compared with that of the previous model for tungsten skarn deposits prepared by Menzie and others (1992). Dashed diagonal lines show the amount of contained tungsten metal. The arrows begin at the value in the previous model and point to the updated value in the current model. The current data are from table 2 of this report. 


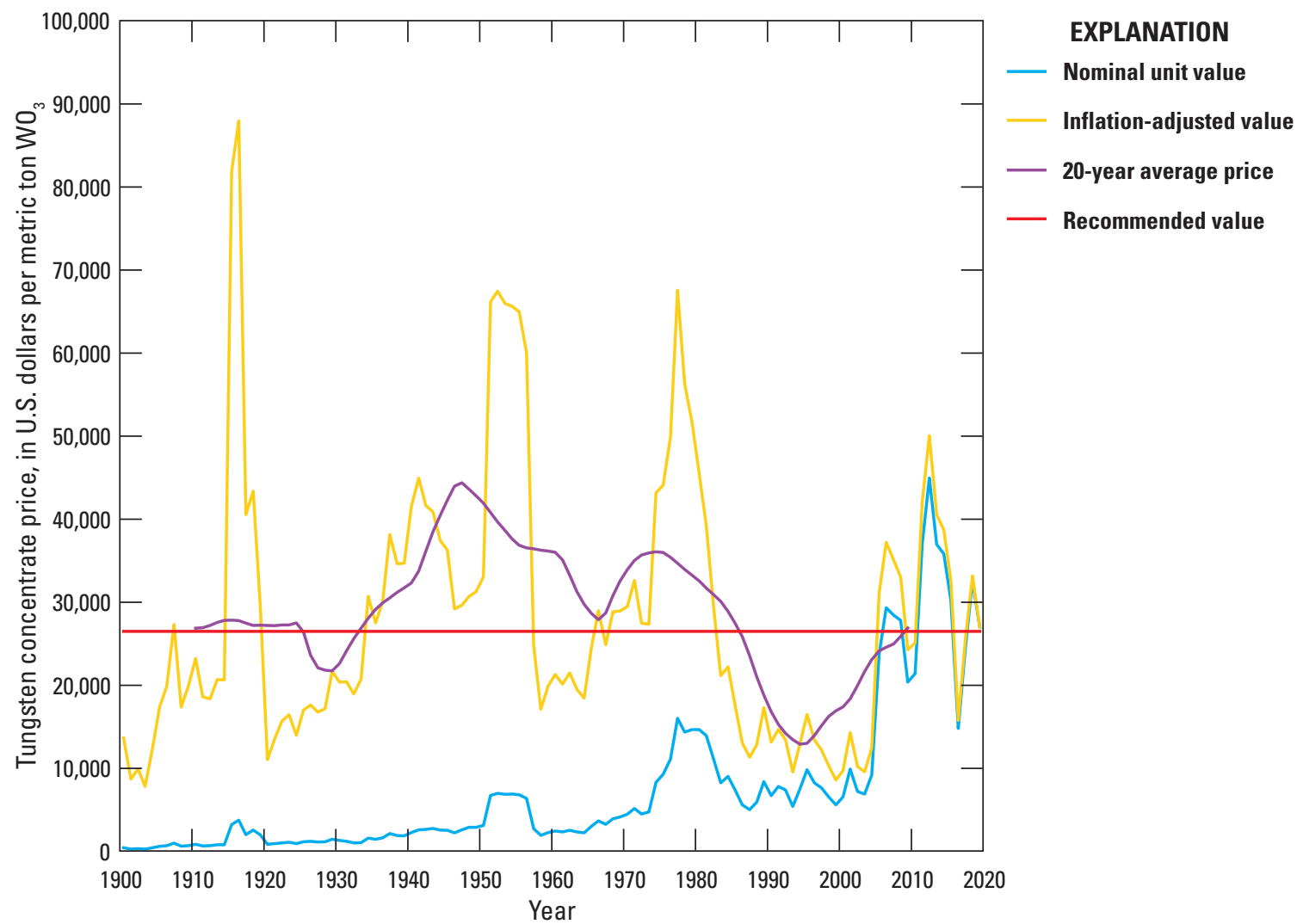

Figure 7. Tungsten concentrate prices from 1900 to 2019, with nominal unit values, inflation-adjusted unit values reported in constant 2019 dollars, long-term 20-year average price, and the recommended value of $\$ 26,500$ per metric ton of $\mathrm{WO}_{3}$. Price data are from the U.S. Geological Survey (2017) and Shedd (2020); inflation factors are from the U.S. Bureau of Labor Statistics (2020).

Table 3. Test run parameters and simulation results for the current tungsten skarn grade and tonnage model and one previous model using MapMark4 and RAEF (Resource Assessment Economic Filter) software.

[Grade and tonnage data are from table 2 of this report and Menzie and others (1992); example deposit estimates are from Ellefsen (2017). KDE, kernel density estimate; PDF, probability distribution function; RAEF, Resource Assessment Economic Filter; $\mathrm{WO}_{3}$, tungsten trioxide; std. dev., standard deviation; $\%$, percentile of deposits]

\begin{tabular}{|c|c|c|c|c|c|c|c|c|c|c|}
\hline \multirow[b]{2}{*}{ Test parameters } & \multicolumn{5}{|c|}{ Contained $\mathrm{WO}_{3}$, in thousand metric tons } & \multicolumn{5}{|c|}{ Recoverable $\mathrm{WO}_{3}$, in thousand metric tons } \\
\hline & Mean & $\begin{array}{l}\text { Std. } \\
\text { dev. }\end{array}$ & $90 \%$ & $50 \%$ & $10 \%$ & Mean & $\begin{array}{l}\text { Std. } \\
\text { dev. }\end{array}$ & $90 \%$ & $50 \%$ & $10 \%$ \\
\hline KDE PDF type, truncated & 72 & 121 & 0 & 22 & 213 & 44 & 77 & 0 & 9 & 133 \\
\hline Normal PDF type, truncated & 69 & 110 & 0 & 23 & 202 & 42 & 70 & 0 & 12 & 127 \\
\hline
\end{tabular}




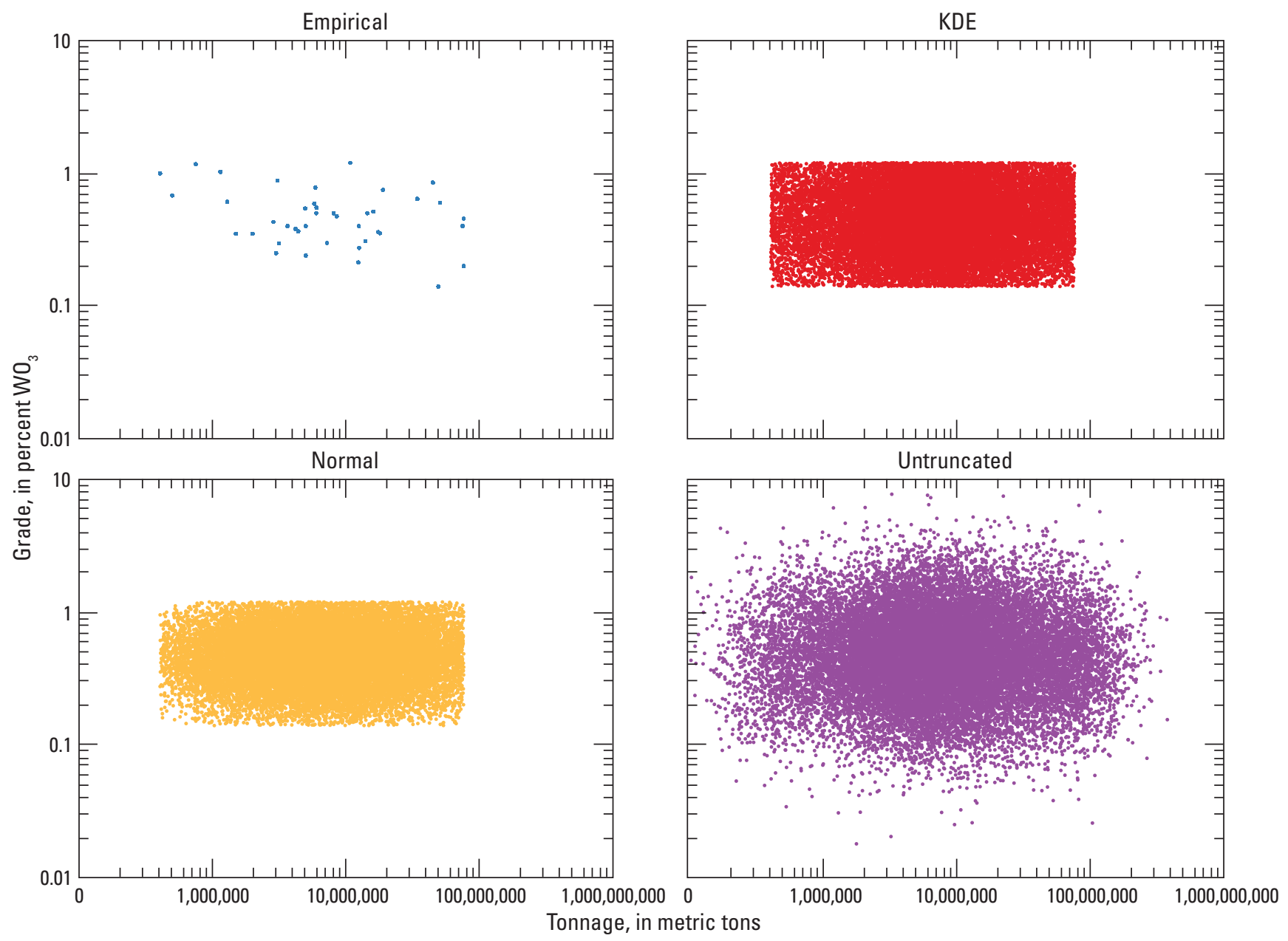

Figure 8. Bivariate plot of log-transformed grade and tonnage for simulation results using different test parameters in MapMark4. Grade and tonnage data are from table 2 of this report; example deposit estimates are from Ellefsen (2017). KDE, kernel density estimate; $\mathrm{WO}_{3}$, tungsten trioxide 


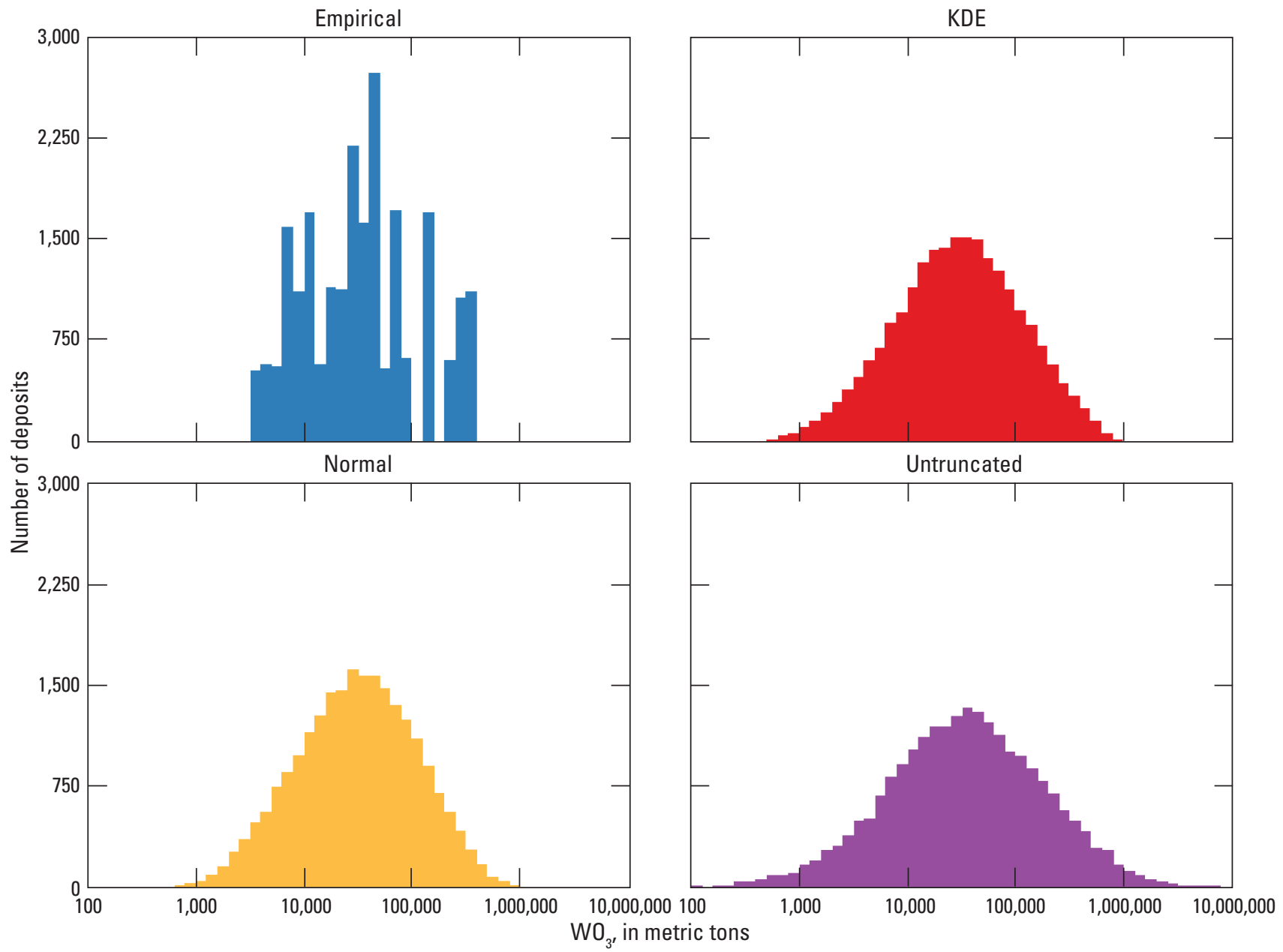

Figure 9. Histograms of contained tungsten trioxide $\left(\mathrm{WO}_{3}\right)$ for simulation results using different test parameters in MapMark4. Grade and tonnage data are from table 2 of this report; example deposit estimates are from Ellefsen (2017). KDE, kernel density estimate 


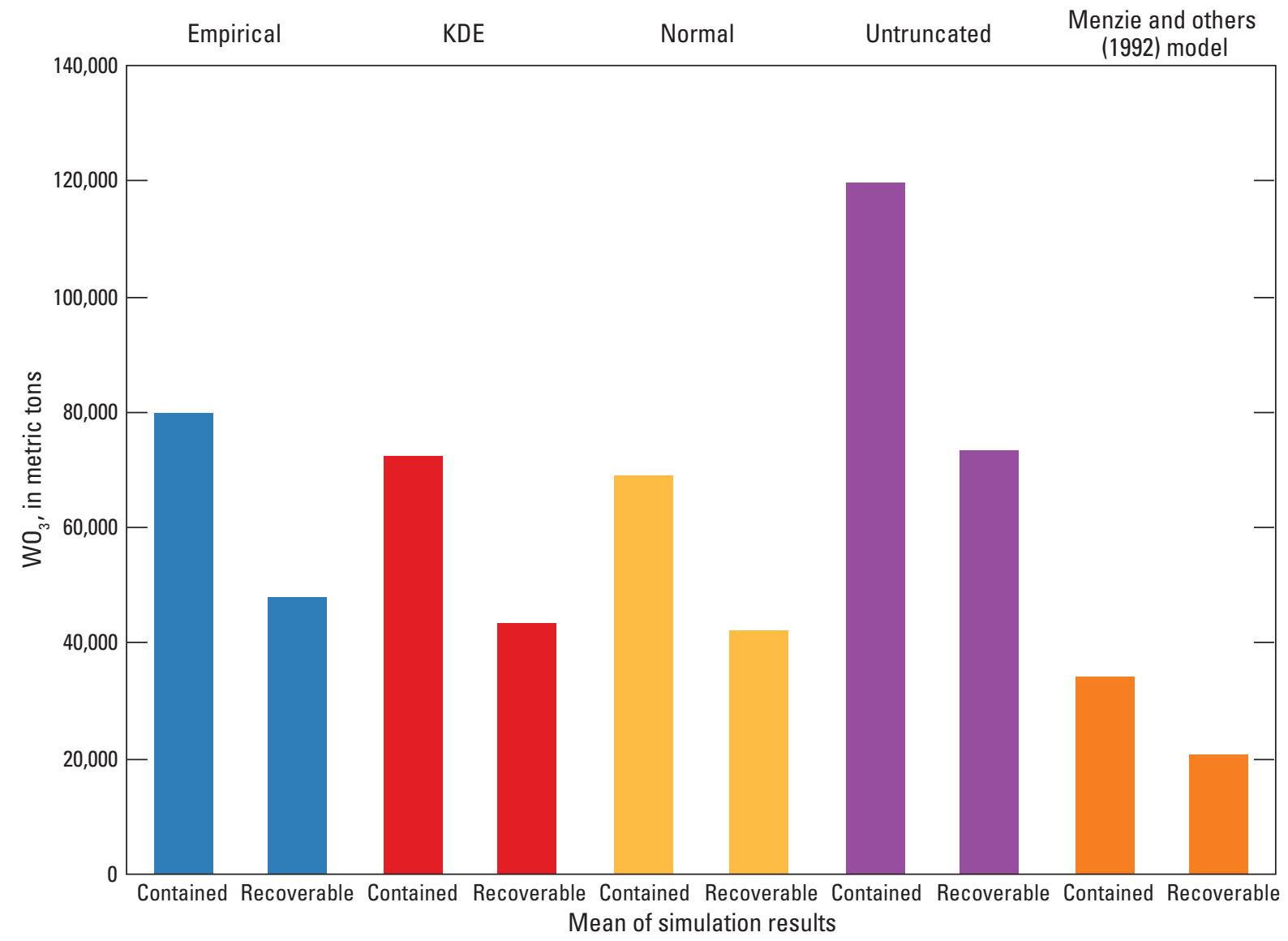

Figure 10. Bar charts comparing the mean contained and recoverable tungsten trioxide $\left(\mathrm{WO}_{3}\right)$ for simulation results using different test parameters in the MapMark4 and RAEF (Resource Assessment Economic Filter) software. Grade and tonnage data are from table 2 of this report and Menzie and others (1992); example deposit estimates are from Ellefsen (2017). KDE, kernel density estimate

\section{Conclusion}

The grade and tonnage model presented here is the first attempt to incorporate new mineral inventory data related to tungsten skarns in nearly 30 years. The model adds additional deposits not present in the previous global tungsten skarn grade and tonnage model for a total of 41 deposits. The median tonnage has increased by approximately 5 million metric tons, whereas the median grade has decreased by $0.2 \%$. This trend is reflective of the economic factors driving a modern tendency to mine larger tonnage, lower grade deposits, and the ability to operate at lower cutoff grades. The incorporation and analysis of new data have resulted in a model that is well-suited to facilitating modern assessments of undiscovered tungsten skarn resources. The need for periodic reevaluation of existing models is demonstrated by the application of modern software tools, and recommendations for optimizing their implementation are critical to appropriately estimating the economic potential of undiscovered deposits. The selection of an appropriate grade and tonnage model has strong effects on the results of quantitative assessments, which can inform policy decisions, land-use planning, and Federal stewardship of natural resources.

\section{References Cited}

Almonty Industries, 2013, Management discussion and analysis - For the three and twelve month periods ended September 30, 2013: Almonty Industries, December 19, 29 p., accessed July 15, 2019, at https://www.sedar.com/GetFile.do?lang=EN\&docClass= $7 \&$ issuerNo $=00029658 \&$ issuerType $=03 \&$ projectNo $=$ $02148731 \&$ doc Id $=3455365$. 
Almonty Industries, 2016, Management discussion and analysis - For the three and twelve month periods ended September 30, 2015: Almonty Industries, February 9, 42 p., accessed July 15, 2019, at https://www.sedar.com/GetFile.do?lang=EN\&docClass= $7 \&$ issuerNo $=00029658 \&$ issuerType $=03 \&$ project $\mathrm{No}=$ $02442321 \&$ doc Id $=3861493$.

Audion, A.S., 2013, Étude pilote d'une cible minière en métropole - Le gistment de tungstène de Fumade (Tarn) - Rapport final: Bureau de Recherches Géologiques et Minières (BRGM) report no. RP-62718-FR, 78 p., accessed March 27, 2019, at http://infoterre.brgm.fr/rapports /RP-62718-FR.pdf.

Barton, P.B., Brew, D.A., Ludington, S., Lindsey, D.A., Ayuso, R.A., Force, E.R., Gamble, B.M., Goldfarb, R.J., John, D.A., and Johnson, K.M., 1995, Recommendations for assessments of undiscovered mineral resources: U.S. Geological Survey Open-File Report 95-82, 136 p., accessed March 19, 2020, at https://pubs.er.usgs.gov/ publication/ofr9582.

Camm, T.W., 1991, Simplified cost models for prefeasibility mineral evaluations: U.S. Bureau of Mines Information Circular 9298, 44 p., accessed March 16, 2020, at https://pubs.er.usgs.gov/publication/70138816.

Camm, T.W., 1994, Simplified cost models for prefeasibility mineral evaluations: Mining Engineering, v. 46, no. 6, p. 559-562.

Carroll, T.R., Schmeda, G., Karl, N.A., Burger, M.H., Long, K.R., and Reyes, T.A., 2018, Tungsten deposits in the United States: U.S. Geological Survey data release, accessed February 24, 2020, at https://doi.org/10.5066/ P9XA8MJ4.

Chen, X., Liang, H., Richards, J.P., Huang, W., Zhang, J., $\mathrm{Wu}$, J., and Sotiriou, P., 2018, Age and granite association of skarn W mineralization at Niutangjie district, South China Block: Ore Geology Reviews, v. 102, p. 268-283, accessed February 23, 2019, https://doi.org/10.1016/ j.oregeorev.2018.09.003.

Clow, G., Cox, J., and Rennie, D., 2006, Technical report on the Cantung Mine, Northwest Territories, Canada, National Instrument 43-101 report prepared for North American Tungsten Corporation Ltd.: Scott Wilson Roscoe Postle Associates Inc., December 14, 130 p., accessed June 3, 2019, at https://www.sedar.com/GetFile.do?lang= EN\&docClass $=13 \&$ issuerNo $=00007610 \&$ issuerType $=$ 03\&project $\mathrm{No}=01031931 \&$ docId $=1859963$.

Cox, D.P., ed., 1983, U.S. Geological Survey-Ingeominas mineral resource assessment of Colombia-Ore deposit models: U.S. Geological Survey Open-File Report 83-423, 73 p., accessed March 16, 2020, at https://pubs.er.usgs.gov/ publication/ofr83423.
Cox, D.P., 1986, Descriptive model of W skarn deposits, in Cox, D.P., and Singer, D.A., eds., Mineral deposit models: U.S. Geological Survey Bulletin 1693, p. 55, accessed March 16, 2020, at https://pubs.er.usgs.gov/ publication/b1693.

Cox, D.P., and Singer, D.A., 1986, Mineral deposit models: U.S. Geological Survey Bulletin 1693, 379 p., accessed March 16, 2020, at https://pubs.er.usgs.gov/ publication/b1693

Dai, P., Mao, J., Wu, S., Xie, G., and Luo, X., 2018, Multiple dating and tectonic setting of the Early Cretaceous Xianglushan W deposit, Jiangxi Province, South China: Ore Geology Reviews, v. 95, April, p. 1161-1178, accessed September 16, 2019, at https://doi.org/10.1016/ j.oregeorev.2017.11.017.]

Dawson, K.M., 1984, Skarn tungsten, in Eckstrand, O.R., ed., Canadian mineral deposit types-A geological synopsis: Geological Survey of Canada Economic Geology Report 36, p. 55, accessed March 16, 2020, at https://geoscan.nrcan.gc.ca/starweb/geoscan/ servlet.starweb?path=geoscan/fulle.web\&search1= $\mathrm{R}=120000$.

Delaney, B., and Bakker, F.J., 2014, Technical report on the Cantung Mine, Northwest Territories, Canada [NI 43-101 technical report]: North American Tungsten Corporation Ltd., 148 p., accessed June 3, 2019, at https://www.sedar.com/GetFile.do?lang=EN\&docClass= $24 \&$ issuerNo $=00007610 \&$ issuerType $=03 \&$ project $N_{o}=$ $02273816 \&$ docId $=3628944$.

Deng, X.-H., Chen, Y.-J., Santosh, M., Wang, J.-B., Li, C., Yue, S.-W., Zheng, Z., Chen, H.-J., Tang, H.-S., Dong, L.-H., and Qu, X., 2017, U-Pb zircon, Re-Os molybdenite geochronology and $\mathrm{Rb}-\mathrm{Sr}$ geochemistry from the Xiaobaishitou W (-Mo) deposit-Implications for Triassic tectonic setting in eastern Tianshan, NW China: Ore Geology Reviews, v. 80, p. 332-351, accessed March 17, 2019, at https://doi.org/10.1016/ j.oregeorev.2016.05.013.]

Desautels, P., and Berndt, P., 2018, NI 43-101 resource update for the $\mathrm{RC}$ and $\mathrm{BN}$ Zones and maiden resource estimate for the BK Zone of the Fox Tungsten Project, British Columbia: Happy Creek Minerals Ltd., 181 p., accessed April 16, 2018, at https://www.sedar.com/GetFile.do?lang= EN\&docClass $=24 \&$ issuerNo $=00023793 \&$ issuerType $=$ $03 \&$ project $\mathrm{No}=02756669 \&$ docId $=4295834$. 
Desautels, P., Arsenau, G., and Maunula, T., 2007, Technical report on the Risby tungsten deposit, Yukon, prepared for Playfair Mining Ltd.: Wardrop Engineering Inc., Document no. 0752860100-REP-L0001-00, 91 p., accessed May 15, 2019, at https://www.sedar.com/GetFile.do?lang= $\mathrm{EN} \&$ docClass $=24 \&$ issuerNo $=00000296 \&$ issuerType $=$ $03 \&$ projectNo $=01161509 \&$ docId $=2049933$.

Dick, L.A., and Hodgson, C.J., 1982, The MacTung $\mathrm{W}-\mathrm{Cu}(\mathrm{Zn})$ contact metasomatic and related deposits of the northeastern Canadian Cordillera: Economic Geology and the Bulletin of the Society of Economic Geologists, v. 77, no. 4, p. 845-867, accessed June 6, 2019, at https://doi.org/10.2113/gsecongeo.77.4.845.]

Duval, J.S., 2002, EMINERS-An economic mineral resource simulator: U.S. Geological Survey OpenFile Report 2002-380, accessed March 16, 2020, at https://pubs.er.usgs.gov/publication/ofr02380.

Duval, J.S., 2012, Version 3.0 of EMINERS—Economic Mineral Resource Simulator: U.S. Geological Survey Open-File Report 2004-1344, accessed March 16, 2020, at https://pubs.er.usgs.gov/publication/ofr20041344.

Einaudi, M.T., and Burt, D.M., 1982, Introduction; terminology, classification, and composition of skarn deposits: Economic Geology and the Bulletin of the Society of Economic Geologists, v. 77, no. 4, p. 745-754, accessed May 19, 2019, at https://doi.org/10.2113/gsecongeo.77.4.745.]

Einaudi, M.T., Meinert, L.D., and Newberry, R.J., 1981, Skarn deposits, in Skinner, B.J., ed., Economic GeologySeventy-Fifth anniversary volume (1905-1980): Littleton, Colo., Society of Economic Geologists, p. 317-391.

Ellefsen, K.J., 2017, User's guide for MapMark4—An $\mathrm{R}$ package for the probability calculations in three-part mineral resource assessments: U.S. Geological Survey Techniques and Methods, book 7, chap. C14, 23 p., accessed March 16, 2020, at https://doi.org/10.3133/ tm7C14.

Executive Office of the President, 2017, A Federal strategy to ensure secure and reliable supplies of critical minerals: Federal Register, v. 82, no. 246, p. 60835-60837, accessed December 20, 2019, at https://www.federalregister.gov/ documents/2017/12/26/2017-27899/a-federal-strategy-toensure-secure-and-reliable-supplies-of-critical-minerals.

Fitzpatrick, K., and Bakker, F.J., 2011, Technical report on the Cantung Mine, Northwest Territories, Canada: North American Tungsten Corporation Ltd., 155 p., accessed June 3, 2019, at https://www.sedar.com/GetFile.do?lang= EN\&docClass $=24 \&$ issuerNo $=00007610 \&$ issuerType $=$ $03 \&$ projectNo $=01695835 \&$ docId $=2816408$.
Fortier, S.M., Nassar, N.T., Lederer, G.W., Brainard, J., Gambogi, J., and McCullough, E.A., 2018, Draft critical mineral list-Summary of methodology and background information-U.S. Geological Survey technical input document in response to Secretarial Order No. 3359: U.S. Geological Survey Open-File Report 2018-1021, 15 p., accessed March 3, 2019, at https://doi.org/10.3133/ ofr20181021.

Hammarstrom, J.M., Elliott, J.E., Kotlyar, B.B., Theodore, T.G., Nash, J.T., John, D.A., Hoover, D.B., and Knepper, D.H., Jr., 1995, Sn and (or) W skarn and replacement deposits, in du Bray, E.A. (ed.), Preliminary compilation of descriptive geoenvironmental mineral deposit models: U.S. Geological Survey Open-File Report 95-831, p. 54-61, accessed March 16, 2020, at https://pubs.er.usgs.gov/publication/ ofr95831.

Hammarstrom, J.M., Zientek, M.L., Parks, H.L., and Dicken, C.L., 2019, Assessment of undiscovered copper resources of the world, 2015 (ver.1.1, May 24, 2019): U.S. Geological Survey Scientific Investigations Report 2018-5160, 619 p., accessed March 3, 2020, at https://doi.org/10.3133/sir20185160.

Heemskirk Consolidated Ltd., 2008, Annual report 2008: Heemskirk Consolidated Ltd., 108 p., accessed January 28, 2020, at https://web.archive.org/web/ 20170419040947/http:/heemskirk.com/files/uploads /Annual\%20Report\%202008.pdf.

Heemskirk Consolidated Ltd., 2009, Annual report 2009: Heemskirk Consolidated Ltd., 112 p., accessed January 28, 2020, at https://web.archive.org/web/ 20170418154506/http:/heemskirk.com/files/uploads/ HEEM0155\%20-\%20Heemskirk\%20AR09\%20 Final\%20R1.pdf.

Heemskirk Consolidated Ltd., 2010, Annual report 2010: Heemskirk Consolidated Ltd., 68 p., accessed January 28, 2020, at https://web.archive.org/web/ 20110216033155/http://www.heemskirk.com/public_reports/ Annual_Reports $/ 2010 \% 20$ Annual $\% 20$ Report $\% 20$ for $\% 20$ release.pdf.

Japan-Kazakhstan Network for Investment Environment Improvement, 2015, Bayan Field—Kazakhstan: JapanKazakhstan Network for Investment Environment Improvement, 8 p., accessed March 16, 2020, at http://www.jp-kz.org/data/proposal/7.\%20Aksoran,\%20 Bayan,\%20Stanislavskoe.pdf.

Jingwen, M., Yanbo, C., Maohong, C., and Pirajno, F., 2013, Major types and time-space distribution of Mesozoic ore deposits in South China and their geodynamic settings: Mineralium Deposita, v. 48, no. 3, p. 267-294, accessed October 23, 2019, at https://doi.org/10.1007/s00126012-0446-z.] 
John, D.A., and Bliss, J.D., 1993, Grade and tonnage model of tungsten skarn deposits, Nevada: U.S. Geological Survey Open-File Report 94-5, 35 p., accessed February 24, 2020, at https://pubs.er.usgs.gov/publication/ofr945.

Kotlyar, B.B., Ludington, S.D., and Mosier, D.L., 1995, Descriptive, grade, and tonnage models for molybdenumtungsten greisen deposits: U.S. Geological Survey OpenFile Report 95-584, 30 p., accessed March 16, 2020, at https://pubs.er.usgs.gov/publication/ofr95584.

Lacroix, P.A., and Cook, R.B., 2007, Technical report on the Mactung tungsten deposit, MacMillan Pass, Yukon, prepared for North American Tungsten Corporation Limited [NI 43-101 technical report]: Scott Wilson Roscoe Postle Associates Inc., 126 p., accessed May 7, 2019, at https://www.sedar.com/GetFile.do?lang=EN\&docClass= $24 \&$ issuerNo $=00007610 \&$ issuerType $=03 \&$ projectNo $=$ $01095069 \&$ docId $=1969916$.

Maya Gold \& Silver Inc., 2019, Maya Gold \& Silver reports results of surface and underground sampling at Azegour property: Maya Gold \& Silver Inc. press release, 7 p., accessed January 27, 2020, at https://www.sedar.com/GetFile.do?lang=EN\&docClass= $8 \&$ issuerNo $=00026913 \&$ issuerType $=03 \&$ projectNo $=$ $02937368 \&$ doc Id $=4551921$.

McCandlish, K., and Odell, M., 2013, Preliminary economic assessment of the Springer Tungsten Mine, Pershing County, Nevada, USA (as amended \& restated), prepared for Silver Predator Corp.: DMT Geosciences, 127 p., accessed August 27, 2019, at https://www.sedar.com/GetFile.do? lang $=\mathrm{EN} \&$ docClass $=24 \&$ issuerNo $=00026569 \&$ issuerType $=$ $03 \&$ projectNo $=02196120 \&$ docId $=3519722$.

Mead, R.D., Kesler, S.E., Foland, K.A., and Jones, L.M., 1988, Relationship of Sonoran tungsten mineralization to the metallogenic evolution of Mexico: Economic Geology and the Bulletin of the Society of Economic Geologists, v. 83 , no. 8, p. 1943-1965, accessed November 1, 2019, at https://doi.org/10.2113/gsecongeo.83.8.1943.

Meinert, L.D., Dipple, G.M., and Nicolescu, S., 2005, World skarn deposits, in Hedenquist, J.W., Thompson, J.F.H., Goldfarb, R.J., and Richards, J.P., eds., Economic GeologyOne hundredth anniversary volume, 1905-2005: Littleton, Colo., Society of Economic Geologists, p. 299-336, accessed November 15, 2019, at https://doi.org/10.5382/AV100.11.

Menzie, W.D., and Jones, G.M., 1983, Tungsten skarn, in Singer, D.A., and Mosier, D.L., eds., Mineral deposit grade-tonnage models: U.S. Geological Survey Open-File Report 83-623, p. 49-51, accessed March 19, 2020, at https://pubs.er.usgs.gov/publication/ofr83623.
Menzie, W.D., and Jones, G.M., 1986, Grade and tonnage model of W skarn deposits, in Cox, D.P., and Singer, D.A., eds., Mineral deposit models: U.S. Geological Survey Bulletin 1693, p. 55-57 accessed March 19, 2020, at https://pubs.er.usgs.gov/publication/b1693.

Menzie, W.D., Jones, G.M., and Elliott, J.E., 1992, TungstenGrades and tonnages of some deposits, in DeYoung, J.H., Jr., and Hammarstrom, J.M., eds., Contributions to commodity geology research: U.S. Geological Survey Bulletin 1877, p. J1-J7, accessed March 19, 2020, at https://pubs.er.usgs.gov/publication/b1877.

Narciso, H., Iakovlev, I., de Ruijter, M.A., Impey, G., Cowie, S., Tanase, A., Nichols, A., Collins, J., Goodall, N., Lacroix, P., and Trimble, R., 2009, Amended technical report on the Mactung property, prepared for North American Tungsten Corporation Ltd.: Wardrop Engineering Inc., Document No. 1053390100-REP-R0001-00, 372 p., accessed February 13, 2019, at http://www.natungsten.com/i/pdf/TechReport-Mactung.pdf.

Newberry, R.J., 1982, Tungsten-bearing skarns of the Sierra Nevada; I, The Pine Creek Mine, California: Economic Geology and the Bulletin of the Society of Economic Geologists, v. 77, no. 4, p. 823-844, accessed May 3, 2019, at https://doi.org/10.2113/gsecongeo.77.4.823.]

Nokleberg, W.J., 1981, Geologic setting, petrology, and geochemistry of zoned tungsten-bearing skarns at the Strawberry Mine, central Sierra Nevada, California: Economic Geology and the Bulletin of the Society of Economic Geologists, v. 76, no. 1, p. 111-133, accessed August 27, 2019, at https://doi.org/10.2113/ gsecongeo.76.1.111.]

North American Tungsten Corporation Ltd, 2003, Annual information form: North American Tungsten Corporation Ltd., February 14, 66 p., accessed June 3, 2019, at https://www.sedar.com/GetFile.do?lang=EN\&docClass= $1 \&$ issuerNo $=00007610 \&$ issuerType $=03 \&$ projectNo $=$ $00513873 \&$ docId $=997438$.

North American Tungsten Corporation Ltd, 2007, Annual report 2007-The tungsten mining company: North American Tungsten Corporation Ltd., 40 p., accessed June 3, 2019, at https://www.sedar.com/GetFile.do?lang= $\mathrm{EN} \&$ docClass $=2 \&$ issuerNo $=00007610 \&$ issuerType $=$ $03 \&$ projectNo $=01210409 \&$ docId $=2119677$.

Obolenskiy, A.A., Rodionov, S.M., Dejidmaa, G., Gerel, O., Hwang, D.H., Miller, R.J., Nokleberg, W.J., Ogasawara, M., Smelov, A.P., Yan, H., and Seminskiy, Z.V., 2013, Metallogenic belt and mineral deposit maps of Northeast Asia: U.S. Geological Survey Scientific Investigations Map 3022, 4 sheets, scales 1:7,500,000 and 1:15,000,000, accessed March 16, 2020, at https://pubs.usgs.gov/ $\operatorname{sim} / 3022 /$. 
Peel Mining Ltd., 2018, Annual report 2018: Peel Mining Ltd., 74 p., accessed March 3, 2018, at http://www.peelmining.com.au/wp-content/uploads/2018/ 09/Peel_Annual-Report_2018-FINAL.pdf.

Pitfield, P., and Brown, T., 2011, Mineral profilesTungsten: British Geological Survey, 34 p., accessed March 11, 2020, at https://www.bgs.ac.uk/mineralsuk/ statistics/mineralProfiles.html.

Playfair Mining Ltd, 2009, Risby tungsten deposit resource increases by 37\%: Playfair Mining Ltd. news release, 2 p., accessed February 15, 2019, at https://www.sedar.com/GetFile.do?lang=EN\&docClass= $8 \&$ issuerNo $=00000296 \&$ issuerType $=03 \&$ projectNo $=$ $01421725 \&$ docId $=2422149$.

Price, B.J., and Giroux, G., 2015, 2015 technical (NI-43-101) report and resource estimate, Covas tungsten deposit, prepared for Blackheath Resources, Inc., and Avrupa Minerals Ltd.: B.J. Price Geological Consultants Inc. and Giroux Consultants Ltd., 130 p., accessed July 27, 2019, at http://www.blackheathresources.com/i/pdf/reports/2015-0507_Covas_NI43-101.pdf.

Qi, H.-W., Hu, R.-Z., Wang, X.-F., Qu, W.-J., Bi, X.-W., and Peng, J.-T., 2012, Molybdenite Re-Os and muscovite 40Ar/39Ar dating of quartz vein-type $\mathrm{W}-\mathrm{Sn}$ polymetallic deposits in Northern Guangdong, South China: Mineralium Deposita, v. 47, no. 6, p. 607-622, accessed July 25, 2019, at https://doi.org/10.1007/s00126-012-0406-7.

Rabchevsky, G.A., 1988, The tungsten industry of the U.S.S.R.: U.S. Bureau of Mines Mineral Issues, 50 p., accessed January 23, 2020, at https://digital.library.unt.edu/ ark:/67531/metadc40315/.

Ray, G.E., 1995, W Skarns, in Ray, G.E., and Lefebure, D.V., eds., Selected British Columbia mineral deposit profiles, volume 1-Metallics and coal: British Columbia Ministry of Employment and Investment Open File 1995-20, p. 71-74, accessed March 16, 2020, at https://www2.gov.bc.ca/gov/content/industry/mineralexploration-mining/british-columbia-geological-survey/ publications/openfiles-1999-1990\#OF1995-20.

Schubert, W.-D., Lassner, E., and Walser, P., 2006, Geology of tungsten: International Tungsten Industry Association Newsletter, December, p. 2-10, accessed January 29, 2020, at https://itia.info/assets/files/Newsletter_2006_12.pdf.

Shapiro, J.L., and Robinson, G.R., Jr., 2019, Resource Assessment Economic Filter (RAEF) - A graphical user interface supporting implementation of simple engineering mine cost analyses of quantitative mineral resource assessment simulations: U.S. Geological Survey Techniques and Methods, book 7, chap. C23, 18 p., accessed March 16, 2020 , at https://pubs.er.usgs.gov/publication/tm7C23.
Shedd, K.B., II, 2020, Tungsten: U.S. Geological Survey Mineral Commodity Summaries 2020, p. 178-179, accessed March 2, 2020, at https://doi.org/10.3133/mcs2020.]

Sinclair, W.D., Gonevchuk, G.A., Korostelev, P.G., Semenyak, B.I., Rodionov, S.M., Seltmann, R., and Stemprok, M., 2014, World tin and tungsten deposit database: Geological Survey of Canada Open File 7688, 6 p., accessed October 31, 2019, at https://doi.org/10.4095/295581.

Singer, D.A., 1993, Basic concepts in three-part quantitative assessments of undiscovered mineral resources: Nonrenewable Resources, v. 2, no. 2, p. 69-81, accessed October 30, 2019, https://doi.org/10.1007/BF02272804.

Singer, D.A., 2007, Short course introduction to quantitative mineral resource assessments: U.S. Geological Survey OpenFile Report 2007-1434, 13 p., accessed March 27, 2020, at https://pubs.usgs.gov/of/2007/1434/.

Singer, D.A., and Menzie, W.D., 2010, Quantitative mineral resource assessments-An integrated approach: New York, Oxford University Press, 219 p.

Soloviev, S.G., 2011, Geology, mineralization, and fluid inclusion characteristics of the Kensu W-Mo Skarn and Mo-W-Cu-Au alkalic porphyry deposit, Tien Shan, Kyrgyzstan: Economic Geology and the Bulletin of the Society of Economic Geologists, v. 106, no. 2, p. 193-222, accessed January 3, 2019, at https://doi.org/10.2113/ econgeo.106.2.193.]

Soloviev, S.G., and Kryazhev, S.G., 2018, Tungsten mineralization in the Tien Shan gold belt - Geology, petrology, fluid inclusion, and stable isotope study of the Ingichke reduced tungsten skarn deposit, western Uzbekistan: Ore Geology Reviews, v. 101, p. 700-724, accessed May 17, 2019, at https://doi.org/10.1016/j.oregeorev.2018.08.020.

Soloviev, S.G., Kryazhev, S.G., and Dvurechenskaya, S.S., 2019, Genesis of the Maikhura tungsten-tin skarn deposit, Tajik Tien Shan-Insights from petrology, mineralogy, and fluid inclusion study: Ore Geology Reviews, v. 104, p. 561-588, accessed August 2, 2019, at https://doi.org/ 10.1016/j.oregeorev.2018.11.024https://doi.org/10.1016/ j.oregeorev.2018.11.024.

SRK Consulting, 2007, NI 43-101 technical report on resources - Golden Predator Mines, Inc.-Fostung project, Foster Township, Ontario, Canada, prepared for Golden Predator Mines, Inc.: SRK Consulting, 79 p., accessed July 9, 2019, at https://www.sedar.com/GetFile.do?lang= EN\&docClass $=24 \&$ issuerNo $=00025324 \&$ issuerType $=$ $03 \&$ project $\mathrm{No}=01207198 \&$ docId $=2115083$. 
SRK Consulting, 2008, NI 43-101 preliminary assessment, Dublin Gulch property-Mar-Tungsten zone, Mayo District, Yukon Territory, Canada, prepared for StrataGold Corporation: SRK Consulting, 161 p., accessed March 14, 2019, at https://www.sedar.com/GetFile.do?lang= EN\&docClass $=24 \&$ issuerNo $=00020012$ \&issuerType $=$ $03 \&$ project $\mathrm{No}=01331576 \&$ docId $=2322550$.

Stager, H.K., and Tingley, J.V., 1988, Tungsten deposits in Nevada: Reno, Nev., Nevada Bureau of Mines and Geology Bulletin no. 105, 256 p.

Thor Mining Plc, 2018, Increased mineral resource estimate-Pilot Mountain Nevada USA: Thor Mining Plc news release, December 13, accessed January 23, 2020, at https://www.londonstockexchange.com/news-article/ THR/pilot-mountain-increased-mineral-resource-estimate/ 13902358.

Thor Mining Plc, 2019, Annual report 2019: Thor Mining Plc, 59 p., accessed November 19, 2019, at https:/www.thormining.com/sites/thormining/media/pdf/ Annual-and-Interim-Reports/2019-ANNUAL-REPORTASX-THR-final-signed.pdf.

Tungsten Mining NL, 2015, Kilba Mineral resource update: Tungsten Mining NL ASX announcement, 20 p., accessed January 21, 2019, at https:/www.tungstenmining.com/ wp-content/uploads/2015/02/0115-Kilba-Mineral-ResourceUpdate-30-Jan-2015.pdf.

United Nations, 1991, Atlas of mineral resources of the ESCAP region-Volume 8-Bhutan-Explanatory brochure: United Nations, 56 p., accessed March 16, 2020, at https://digitallibrary.un.org/record/150564.

U.S. Bureau of Labor Statistics, 2020, Consumer price index for all urban consumers: U.S. Bureau of Labor Statistics Consumer Price Index (CPI) Databases, accessed March 2, 2020, at https://www.bls.gov/cpi/data.htm.

U.S. Geological Survey, 2017, Tungsten statistics, in Kelly, T.D., and Matos, G.R., (comps.), Historical statistics for mineral and material commodities in the United States (2017 version): U.S. Geological Survey Data Series 140, accessed March 2, 2020, at https://www.usgs.gov/centers/ $\mathrm{nmic} /$ historical-statistics-mineral-and-material-commoditiesunited-states.

Vital Metals Ltd., 2014a, Watershed feasibility study confirms strong economics for 2.5Mtpa tungsten operation: Vital Metals Ltd. ASX-Media announcement, 30 p., September 17, accessed January 23, 2020, at https:/www.vitalmetals.com.au/wp-content/sharelink/ 20140917-watershed-dfs-confirms-strong-economics--25mtpa-project-9eec7e280b618ac576bcc212ddcb5c1a.pdf.
Vital Metals Ltd., 2014b, Annual report 2014: Vital Metals Ltd., 60 p., accessed January 23, 2020, at https:/www.vitalmetals.com.au/wp-content/uploads/2016/ 10/VITAMET-Annual-Report-2014.pdf.

Werner, A.B.T., Sinclair, W.D., and Amey, E.B., 2014, International strategic mineral issues summary reportTungsten: U.S. Geological Survey Circular 930-O (ver. 1.1, November 2014), 74 p., accessed March 16, 2020, at https://pubs.er.usgs.gov/publication/cir930O. [Supersedes version 1.0 published in 1998; revisions in 2014 by John H. DeYoung, Jr., and Kim B. Shedd.]

Wheeler, A., 2015, Technical report on the mineral resources and reserves of the Los Santos Mine Project, Spain, prepared for Daytal Resources Spain S.L. [NI 43-101 technical report]: Adam Wheeler Mining Consultant, 119 p., accessed April 20, 2018, at https://almonty.com/wp-content/ uploads/2019/06/Los_Santos_43-101_Tech_Rep_Oct15_ SEDAR.pdf.

Wheeler, A., 2016, Technical report on the mineral resources and reserves of the Sangdong project, South Korea, prepared for Almonty Industries [NI 43-101 technical report]: Adam Wheeler Mining Consultant, 254 p., accessed June 13, 2019, at https://almonty.com/wp-content/uploads/2019/06/ Sangdong_43-101_Tech_Rep_July16_final-1.pdf.

Xenith Consulting, 2015, Statement of JORC ore reserves, Dolphin open cut, as at 30 July 2015, prepared for King Island Scheelite Ltd.: Xenith Consulting, September, 20 p., accessed February 18, 2019, at http://www.mrt.tas.gov.au/ mrtdoc/tasxplor/download/15_7300/KISXenithReport.pdf.

Zhao, W.W., Zhou, M.-F., Li, Y.H.M., Zhao, Z., and Gao, J.-F., 2017, Genetic types, mineralization styles, and geodynamic settings of Mesozoic tungsten deposits in South China: Journal of Asian Earth Sciences, v. 137, p. 109-140, accessed July 7, 2019, at https://doi.org/10.1016/ j.jseaes.2016.12.047.

Zhao, W.W., Zhou, M.-F., Williams-Jones, A.E., and Zhao, Z., 2018, Constraints on the uptake of REE by scheelite in the Baoshan tungsten skarn deposit, South China: Chemical Geology, v. 477, p. 123-136, accessed June 12, 2019, at https://doi.org/10.1016/j.chemgeo.2017.12.020. 
For more information about this publication, contact Director

Eastern Mineral and Environmental Resources Science Center U.S. Geological Survey

12201 Sunrise Valley Drive

954 National Center

Reston, VA 20192

Or visit the website at https://www.usgs.gov/centers/emersc

Publishing support provided by the Science Publishing Network, Reston Publishing Service Center

Layout by Jeff Corbett 


\section{$\frac{\mathbb{2}}{3}$}

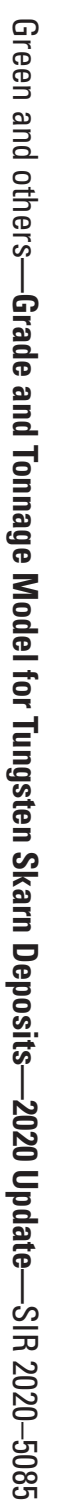

